\title{
Numerical Modelling Analysis for Carrier Concentration Level Optimization of CdTe Heterojunction Thin Film-Based Solar Cell with Different Non-Toxic Metal Chalcogenide Buffer Layers Replacements: Using SCAPS-1D Software
}

\author{
Samer H. Zyoud ${ }^{1,2,3, \text { a }^{*} \text { Ahed H. Zyoud }}{ }^{4, \text { b }}$, Naser M. Ahmed ${ }^{3, \text { c }}$, and Atef Abdelkader ${ }^{1,2, d}$ \\ ${ }^{1}$ Department of Mathematics and Sciences, Ajman University, Ajman, United Arab Emirates \\ ${ }^{2}$ Nonlinear Dynamics Research Center (NDRC), Ajman University, Ajman, United Arab Emirates \\ ${ }^{3}$ School of Physics, Universiti Sains Malaysia, 11800, USM Penang, Malaysia \\ ${ }^{4}$ Department of Chemistry, An-Najah National University, Nablus, Palestine

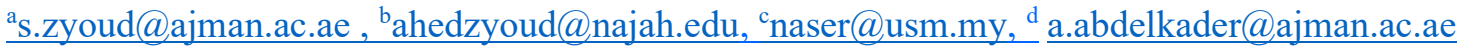

\begin{abstract}
Cadmium telluride (CdTe), a metallic dichalcogenide material, has been utilized as an absorber layer for thin film-based solar cells with appropriate configurations, and the SCAPS-1D structures program has been used to evaluate the results. In both known and developing thin film photovoltaic systems, a CdS thin film buffer layer has been frequently employed as a traditional n-type heterojunction partner. In this study, numerical simulation was used to find a suitable non-toxic material for the buffer layer instead of CdS, among various types of buffer layers $\left(\mathrm{ZnSe}, \mathrm{ZnO}, \mathrm{ZnS}\right.$, and $\left.\mathrm{In}_{2} \mathrm{~S}_{3}\right)$, and carrier concentrations for the absorber layer $\left(\mathrm{N}_{\mathrm{A}}\right)$ and buffer layer $\left(\mathrm{N}_{\mathrm{D}}\right)$ were varied to determine the optimal simulation parameters. carrier concentrations $\left(\mathrm{N}_{\mathrm{A}}\right.$ from $2 \times 10^{12} \mathrm{~cm}^{-3}$ to $2 \times 10^{17} \mathrm{~cm}^{-3}$ and $\mathrm{N}_{\mathrm{D}}$ from $1 \times 10^{16} \mathrm{~cm}^{-3}$ to $1 \times 10^{22} \mathrm{~cm}^{-3}$ ) have been differed. The results showed that the $\mathrm{CdS}$ as buffer layer based CdTe absorber layer solar cell has the highest efficiency $(\eta \%)$ of $17.43 \%$. Furthermore, high conversion efficiencies of $17.42 \%$ and $16.27 \%$ have been found for $\mathrm{ZnSe}$ and $\mathrm{ZnO}$ based buffer layers, respectively. As a result, $\mathrm{ZnO}$ and $\mathrm{ZnSe}$ are potential candidates for replacing the CdS buffer layer in thin-film solar cells. Here, the absorber (CdTe) and buffer ( $\mathrm{ZnSe}$ ) layers were chosen to improve the efficiency by finding the optimal density of the carrier concentration (acceptor and donor). The simulation findings above provide helpful recommendations for fabricating high-efficiency metal oxide-based solar cells in the lab.
\end{abstract}

Keywords: Absorber Layer and Buffer Layer; CdTe; ZnSe; Conversion Efficiency; SCAPS-1D; Solar Cell. 


\section{Introduction}

The challenge of global warming has prompted further study of solar and other renewable energy sources. Solar cells are a fundamental component of solar energy. Different materials are used to make solar cells, with silicon being the most commercially feasible and prevalent. The majority of the alternative materials were developed with the goal of producing low-cost, high-efficiency, and long-lasting solar cells. Although the efficiency is still modest, Nanostructured Metal Oxide Solar Cells have moved a step farther in delivering clean, cheap, and sustainable solar cells [1]. Solar energy conversion to useable power using a solid-state pn-junction based photovoltaic (PV) device offers enormous promise in the effort to reduce our current reliance on fossil fuels and, as a result, reduce harmful greenhouse gas emissions $[2,3]$.

Due to its unique properties, Cadmium Telluride (CdTe) thin film is widely employed in a variety of optical and electrical applications. CdTe thin film cells are gaining popularity because of their abundant, excellent efficiency, long-term stability, and low cost of manufacture [4], such as nanodevices, sensors, and solar cells [5]. CdTe is classified as an II-VI transition metallic dichalcogenide with a high absorption coefficient $\left(>10^{5} \mathrm{~cm}^{-1}\right)$ that is greater than other known semiconductor materials with a narrow band gap $\left(E_{g} \sim 1.5 \mathrm{eV}\right)[6,7]$. This band gap value is suitable for the visible solar light spectrum [8-10].

CdTe, in the form of p-type semiconductors, is a potential absorbing material for thin-film PV technology [11]. Despite the widespread usage of CdTe thin films, its primary form has a low conversion efficiency in PEC procedures. When electrodeposited on Ni substrates, CdTe thin films have poor conversion efficiency, depending on the redox couplings and the type of conduction utilized [12]. PEC performance was also poor when CdTe thin films were formed on FTO or ITO substrates $[13,14]$. When CdTe films were deposited by spray pyrolysis [15], the conversion efficiency was $3.4 \%$, whereas chemical bath formed films by treatment with $\mathrm{CdCl}_{2}$ had a conversion efficiency of $2.5 \%$ [16-18]. CdTe thin film has been reported to have a conversion efficiency of $17.5 \%$ or more under certain circumstances [19]. To increase low PEC performance, CdTe thin films are frequently combined with other systems, such as CdS films [13, 20]. Cadmium sulfide $(\mathrm{CdS})$ is a well-known II-VI compound semiconductor with excellent transparency, a straight band gap transition $(\mathrm{Eg} \sim 2.4 \mathrm{eV})$, strong electron affinity $(\sim 4.2 \mathrm{eV})$, and n-type conductivity [21, 22]. CdS also 
enhances the interface fit of lattice heterojunctions, increases the surplus carrier lifetime, and optimizes the band alignment of the devices in which it is utilized [23]. The optical, electrical, and structural properties of CdS films are useful in a wide variety of scientific, technical, and commercial applications involving optoelectronic devices, particularly solar cells [24]. Due to its properties of low surface recombination and little absorption loss, CdS is a promising option for use as a buffer layer in CdTe thin film-based solar cells. Cadmium (Cd), on the other hand, is a metal that, due to its high toxicity, can be hazardous to the environment and human health. Different materials with a larger band gap, as well as non-toxic compounds like $\mathrm{ZnS}(\mathrm{O}, \mathrm{OH})$ and $\mathrm{ZnS}$, have been studied as suitable buffer layers for thin film solar cells [25-27]. However, because of the complex reaction mechanism and light soaking effects of these buffer layers, cell durability and repeatability may be compromised [28].

$\mathrm{CdS} / \mathrm{CdTe}$ thin films produced on ITO substrates had a conversion efficiency of $3.5 \%$, and when silver (Ag) was coated on the films, the conversion efficiency increased to $9.82 \%$ [29]. Multijunction $\mathrm{CdTe} / \mathrm{CdS}$ combinations Conversion efficiencies of 13\% have also been recorded [30]. Multi-junction CdS/CdTe/ZnTe/ZnTe:Cu cells have a high conversion efficiency of $13.38 \%$ [31, 32]. The efficiency of the $\mathrm{CdS} / \mathrm{CdTe} \mathrm{Cu} / \mathrm{CNT}$ structure has been reported to be up to $14.1 \%$ [33]. The buffer layer connects the absorber and window layers, and it's important for a variety of reasons, including providing structural stability for the thin film and preventing static electricity in the absorber layer [34, 35].

In heterojunction thin-film solar cells, the buffer layer generally serves as a focus point. The photons that reach the absorption layer through the reach-in layer travel via the buffer layer. As a result, the number of photons lost due to absorption in the buffer layer should be kept to a minimum. As a result, in the buffer layer, electrical resistance and minimal surface recombination are required. In order to provide the buffer layer between the absorber layer and the transparent window layer, it is necessary to provide thin-film solar cell stability. As a result, the buffer layer must have a large energy gap. This permits the majority of visible light to pass through to the absorption layer. On the other hand, in order for the depletion layer to overlap, the bandgap margins of the buffer and the absorption layer should be roughly compatible. In heterojunction thin-film solar cells, metal chalcogenides as CdS, CdSe, $\mathrm{ZnS}, \mathrm{ZnSe}$, and $\operatorname{In}_{2} \mathrm{~S}_{3}$ are ideal for the role of a buffer layer. CdS, CdSe, and CdTe are the most popular metal chalcogenide compounds used in thin-film solar cells with heterojunctions. These substances are harmful to the environment. Green and less dangerous chemicals (such as $\mathrm{ZnS}, \mathrm{ZnSe}, \mathrm{ZnO}, \mathrm{Zn}_{1-\mathrm{x}} \mathrm{Mg}_{\mathrm{x}} \mathrm{O}$, and $\mathrm{In}_{2} \mathrm{~S}_{3}$ ) should be studied and assessed as a substitute for the traditional hazardous semiconductors used in 
heterojunction thin-film solar cells [36]. Numerical simulations may be used to investigate the influence of various materials on the final properties of solar cells. The results of such numerical research and analyses can be utilized to improve the device's performance [35, 37-39]. The optimum and best structure of thin film-based solar cells is determined by numerical modeling. There is currently a scarcity of thin-film solar cell simulation research. As a result, we have narrowed the scope of our numerical simulation in this work by utilizing SCAPS-1D software to investigate the needed material for the buffer layer and substituting the CdS with another material. A different buffer layer's effect on cell performance has been investigated. Different buffer layer materials $\left(\mathrm{CdS}, \mathrm{ZnO}, \mathrm{ZnSe}, \mathrm{In}_{2} \mathrm{~S}_{3}, \mathrm{ZnS}\right)$ have been shown to exhibit $\mathrm{J}-\mathrm{V}$ characteristics $\left(\mathrm{V}_{\text {oc }}, \mathrm{J}_{\mathrm{sc}}\right.$, $\mathrm{FF} \%$, and $\eta \%$ ) under standard illumination AM1.5G, $100 \mathrm{~mW} / \mathrm{cm}^{2}, 300 \mathrm{~K}$. (Table 1). The primary goal of this research is to replace $\mathrm{CdS}$ with a different buffer material. Furthermore, the concentration densities of carriers (acceptor and donor) have been considered in this study.

\section{Numerical Modeling and Material Parameters}

SCAPS -1D was created at ELIS, University of Ghent, and it may be used for free in photovoltaic research investigations [40,41]. The SCAPS-1D structures program is frequently used to model the electrical and optical characteristics of AC and DC heterojunctions. It is primarily designed for CIGS and CdTe solar cells. The main goal of SCAPS-1D is to use an existing database to explore the properties of thin film-based solar cells with various buffer layers. SCAPS-1D simulation solutions may be used to examine outputs such as voltage and currents on illumination and dark characteristics. This simulation may also generate a temperature-based analysis. SCAPS-1D simulation may also provide important information such as recombination profiles, current density of individual carriers as a positional function, and electrical physical distribution. The main goal is to replicate solar cells in order to achieve high efficiency before beginning actual experimental manufacturing with various parameters. SCAPS-1D simulation may be used to investigate the impact of various parameters on $\left(\mathrm{V}_{\mathrm{OC}}, \mathrm{J}_{\mathrm{SC}}, \mathrm{FF} \%, \eta \%\right)$ and operating temperature.

\subsection{Numerical Modeling}

SCAPS -1D can solve Poisson's equation for holes and electrons (Eq.1) [42]:

$\frac{d^{2} \Psi}{d x^{2}}=\frac{e}{\epsilon_{o} \epsilon_{r}}\left[P(x)-n(x)+N_{D}-N_{A}+\rho_{P}-\rho_{n}\right]$ 
Where $\Psi$ is electrostatic potential, $e$ is elementary charge, $\epsilon_{r}$ is relative permittivity and $\varepsilon_{o}$ is vacuum permittivity, $p$ is hole concentration, $n$ is electron concentration, $N_{D}, N_{A}$ are donor and acceptor charge concentrations respectively, $\rho_{p}$ and $\rho_{n}$ are holes and electrons distribution, respectively.

Also continuity equation (Eq. 2) [43]:

$\frac{d J_{n}}{d x}=\frac{d J_{p}}{d x}=G-R$

Where $J_{p}$ and $J_{n}$ are hole and electron current densities respectively, $R$ and $\mathrm{G}$ are recombination rates respectively.

Carrier transport occurs by drift and diffusion according to Eq. (3) and Eq. (4), respectively:

$J_{n}=D_{n} \frac{d n}{d x}+\mu_{n} n \frac{d \varphi}{d x}$

$J_{p}=D_{p} \frac{d p}{d x}+\mu_{p} p \frac{d \varphi}{d x}$

Where, $\varphi$ is potential difference, $D_{n}$ and $D_{p}$ are electron and hole diffusion constant, respectively. $\mu_{n}$ and $\mu_{p}$ are electron and hole mobility, $n$ and $p$ are electron and hole carrier concentration.

\subsection{The suggested thin-film solar cell device structure}

Figure 1. shows the thin film's structure, which includes a p-type absorber (CdTe) layer on a Molybdenum (Mo) coated back glass substrate, an n-type buffer layer (CdS, $\operatorname{In}_{2} \mathrm{~S}_{3}, \mathrm{ZnS}, \mathrm{ZnO}$, $\mathrm{ZnSe}$ ), and $\mathrm{SnO}_{2}$ window layer.

\begin{tabular}{|l|}
\hline Front Contact \\
\hline Window Layer $\left(\mathrm{SnO}_{2}\right): \sim 250$ \\
\hline Buffer Layer: $\sim 25 \mathrm{~nm}$ \\
$\left(\mathrm{CdS}, \mathrm{ZnO}, \mathrm{ZnSe}, \mathrm{In}_{2} \mathrm{~S}_{3}, \mathrm{ZnS}\right)$ \\
\hline Absorber Layer $(\mathrm{CdTe}): \sim 2000$ \\
\hline Back Contact $(\mathrm{MO})$ \\
\hline Glass Substrate \\
\hline
\end{tabular}

Figure 1: Schematic diagram of thin film 


\subsection{Numerical Material Parameters}

The starting conditions (bias voltage, operating temperature, lighting, and so on) should be established as stated in Table 1 at the start of the simulation. Table 2 shows the reflection and transmission of the front and back contacts, respectively. Each layer's material characteristics should be entered into a software application. Table 3 shows the material parameter characteristics for the thin film layers lists the physical parameters utilized in the Mo/absorber/buffer/window solar cell simulation [44-61].

Table 1: The working points and illumination

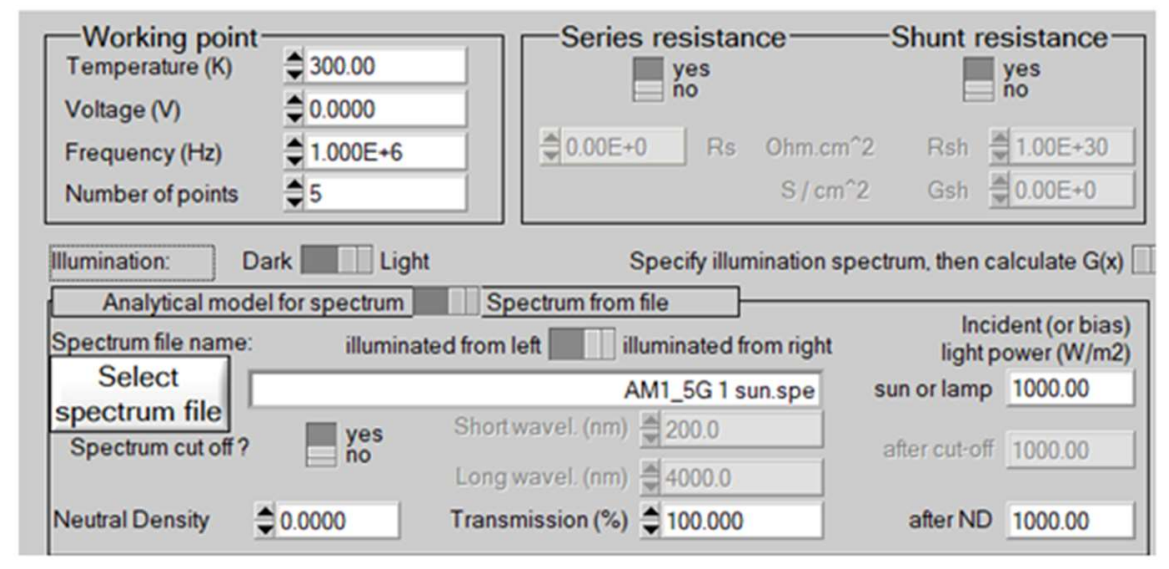

Table 2: Electrical parameters properties of back and front contact used for the metal oxide SCAPS-1D simulation

\begin{tabular}{llll}
\hline Electrical Properties & & Back contact & Front contact \\
\hline Thermionic emission surface & Electron & $1 \times 10^{7}$ & $1 \times 10^{7}$ \\
recombination velocity $(\mathrm{cm} / \mathrm{s})$ & Holes & $1 \times 10^{7}$ & $1 \times 10^{7}$ \\
Metal work function $(\mathrm{eV})$ & & 5 & 4.1 \\
Majority carrier barrier height $(\mathrm{eV})$ & Relative to $\mathrm{E}_{\mathrm{F}}$ & 0.4 & 0.1 \\
& Relative to $\mathrm{E}_{\mathrm{v}}$ or $\mathrm{E}_{\mathrm{C}}$ & -0.1227 & 0.0199 \\
Allow contact tunneling & Effective mass of electron & 1 & 1 \\
& Effective mass of holes & 1 & 1 \\
\hline Optical Properties & Filter Mod & Reflection & Transmission \\
& Filter value & 0.8 & 0.95 \\
& Complement of filter value & 0.2 & 0.05 \\
\hline
\end{tabular}


Table 3: The electrical parameters for the thin film solar cell at 300K.

\begin{tabular}{|c|c|c|c|c|c|c|c|}
\hline & p-CdTe & n- CdS & n- ZnS & n- ZnSe & n- ZnO & $n-I_{2} S_{3}$ & $\mathrm{SnO}_{2}$ \\
\hline Thickness $(\mu \mathrm{m})$ & 2 & 0.025 & 0.025 & 0.025 & 0.025 & 0.025 & 0.25 \\
\hline Band gap (eV) & 1.5 & 2.4 & 3.5 & 2.9 & 3.3 & 2.8 & 3.6 \\
\hline Electron affinity $(\mathrm{eV})$ & 3.9 & 4.5 & 4.5 & 4.09 & 4.45 & 4.7 & 4 \\
\hline Dielectric permittivity (relative) & 9.4 & 10 & 10 & 10 & 9 & 13.5 & 9 \\
\hline CB effective density of states $\left(\mathrm{cm}^{-3}\right)$ & $8 \times 10^{17}$ & $1.5 \times 10^{18}$ & $1.5 \times 10^{18}$ & $1.5 \times 10^{18}$ & $2.2 \times 10^{18}$ & $1.8 \times 10^{19}$ & $2.2 \times 10^{18}$ \\
\hline VB effective density of states $\left(\mathrm{cm}^{-3}\right)$ & $1.8 \times 10^{19}$ & $1.8 \times 10^{18}$ & $1.8 \times 10^{18}$ & $1.8 \times 10^{18}$ & $1.8 \times 10^{19}$ & $4 \times 10^{18}$ & $1.8 \times 10^{18}$ \\
\hline Electron thermal velocity $(\mathrm{cm} / \mathrm{s})$ & $1 \times 10^{7}$ & $1 \times 10^{7}$ & $1 \times 10^{7}$ & $1 \times 10^{7}$ & $1 \times 10^{7}$ & $1 \times 10^{7}$ & $1 \times 10^{7}$ \\
\hline Hole thermal velocity $(\mathrm{cm} / \mathrm{s})$ & $1 \times 10^{7}$ & $1 \times 10^{7}$ & $1 \times 10^{7}$ & $1 \times 10^{7}$ & $1 \times 10^{7}$ & $1 \times 10^{7}$ & $1 \times 10^{7}$ \\
\hline Electron mobility $\left(\mathrm{cm}^{2} / \mathrm{Vs}\right)$ & 300 & 50 & 50 & 50 & 100 & 400 & 100 \\
\hline Hole mobility $\left(\mathrm{cm}^{2} / \mathrm{Vs}\right)$ & 40 & 20 & 20 & 20 & 25 & 210 & 25 \\
\hline Shallow uniform donor density ND $\left(\mathrm{cm}^{-3}\right)$ & 0 & $1 \times 10^{22}$ & $1 \times 10^{22}$ & $1 \times 10^{22}$ & $1 \times 10^{22}$ & $1 \times 10^{22}$ & $1 \times 10^{22}$ \\
\hline Shallow uniform acceptor density NA $\left(\mathrm{cm}^{-3}\right)$ & $2 \times 10^{15}$ & 0 & 0 & 0 & 0 & 0 & 0 \\
\hline
\end{tabular}

\section{Result and discussion}

\subsection{Effect of Different Buffer Layer on thin film-based solar cell}

Cadmium (Cd) is poisonous, and CdS is classified as a carcinogen, both of which are harmful to the environment and humans. Other potential buffer layers, such as $\mathrm{ZnO}, \mathrm{In}_{2} \mathrm{~S}_{3}, \mathrm{ZnSe}$, and $\mathrm{ZnS}$, have been explored as a result. The optimal photovoltaic parameters $\left(V_{O C} . J_{S C}, F F \%\right.$, and $\left.\eta \%\right)$ of the CdTe thin film with various buffer layers are shown in Table 4 and Fig. 2. It should be highlighted that $\mathrm{CdS}$ as a buffer layer performs best, with an efficiency of $17.43 \%$. The results also reveal that buffer layers made of $\mathrm{ZnSe}$ and $\mathrm{ZnO}$ have excellent efficiency, at $17.42 \%$ and 16.27 $\%$, respectively. While buffer layers based on $\mathrm{ZnS}$ and $\operatorname{In}_{2} \mathrm{~S}_{3}$ had a lower efficiency of $15.88 \%$ and $14.23 \%$, respectively. As a result, $\mathrm{ZnO}$ and $\mathrm{ZnSe}$ have been proposed as replacements for CdS as a buffer layer in thin films [62].

Table 4: Effective of the material of buffer (donor) on J-V characteristics.

\begin{tabular}{ccccc}
\hline Buffer Layer & Voc $(\mathbf{V})$ & $\mathbf{J S C}_{\mathbf{S C}}\left(\mathbf{m A} / \mathbf{c m}^{2}\right)$ & $\mathbf{F F \%}$ & Efficiency $(\%)$ \\
\hline $\mathrm{CdS}$ & 0.9113 & 23.4497335 & 81.41 & 17.43 \\
$\mathbf{Z n S e}$ & $\mathbf{0 . 9 1 1 2}$ & $\mathbf{2 3 . 4 8 4 0 3 7}$ & $\mathbf{8 2 . 3 8}$ & $\mathbf{1 7 . 4 2}$ \\
$\mathrm{ZnO}$ & 0.9142 & 23.303926 & 76.37 & 16.27 \\
$\mathrm{ZnS}$ & 0.9121 & 23.260166 & 74.84 & 15.88 \\
$\mathrm{In}_{2} \mathrm{~S}_{3}$ & 0.9198 & 23.153579 & 66.81 & 14.23 \\
\hline
\end{tabular}


(a)

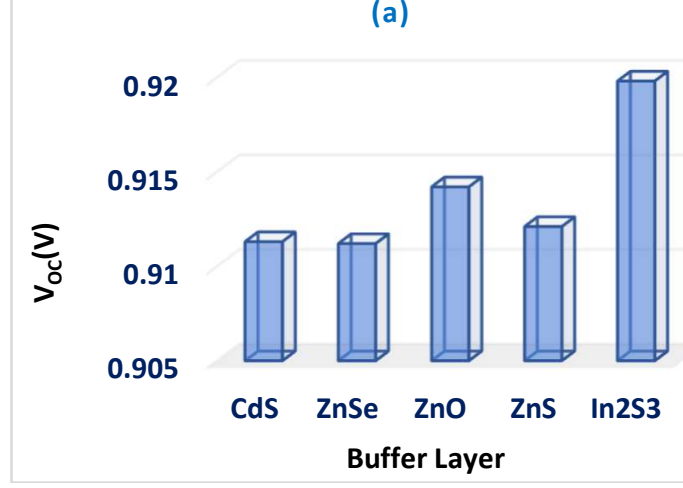

(c)

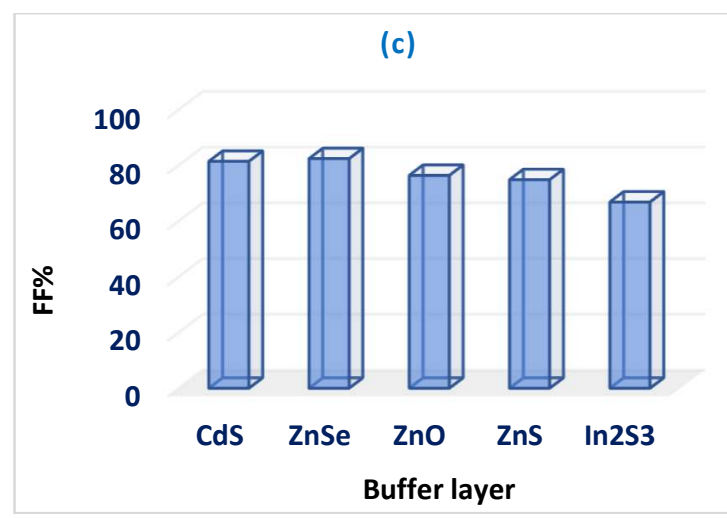

(b)

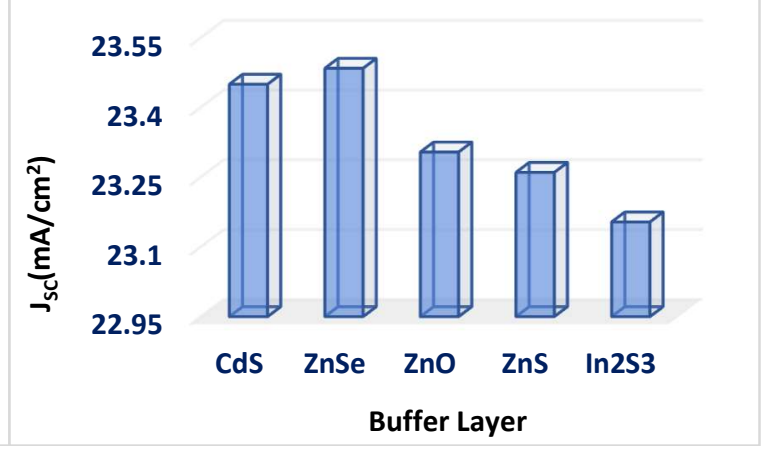

(d)

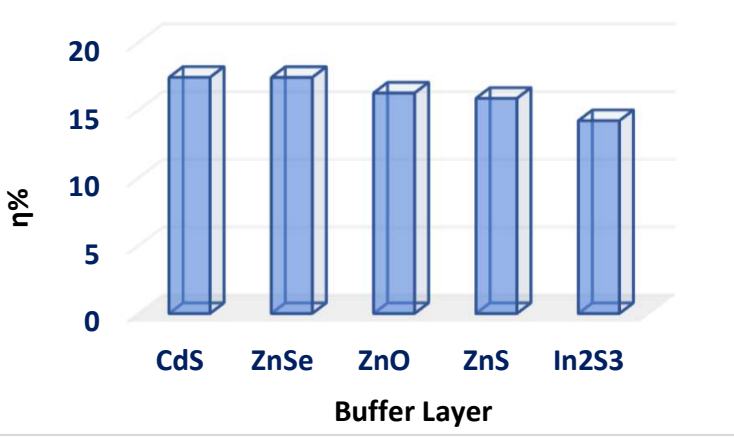

Figure 2: Effective of the material of buffer (donor) layer on photovoltaic parameter (a) $V_{O C}(b) J_{S C}(c) F F \%$ (d) $\eta \%$ 
Figure 3 depicts the $\mathrm{J}-\mathrm{V}$ characteristics for various buffer layers. It's worth noting that when efficiency is great, the curve shifts to the right.

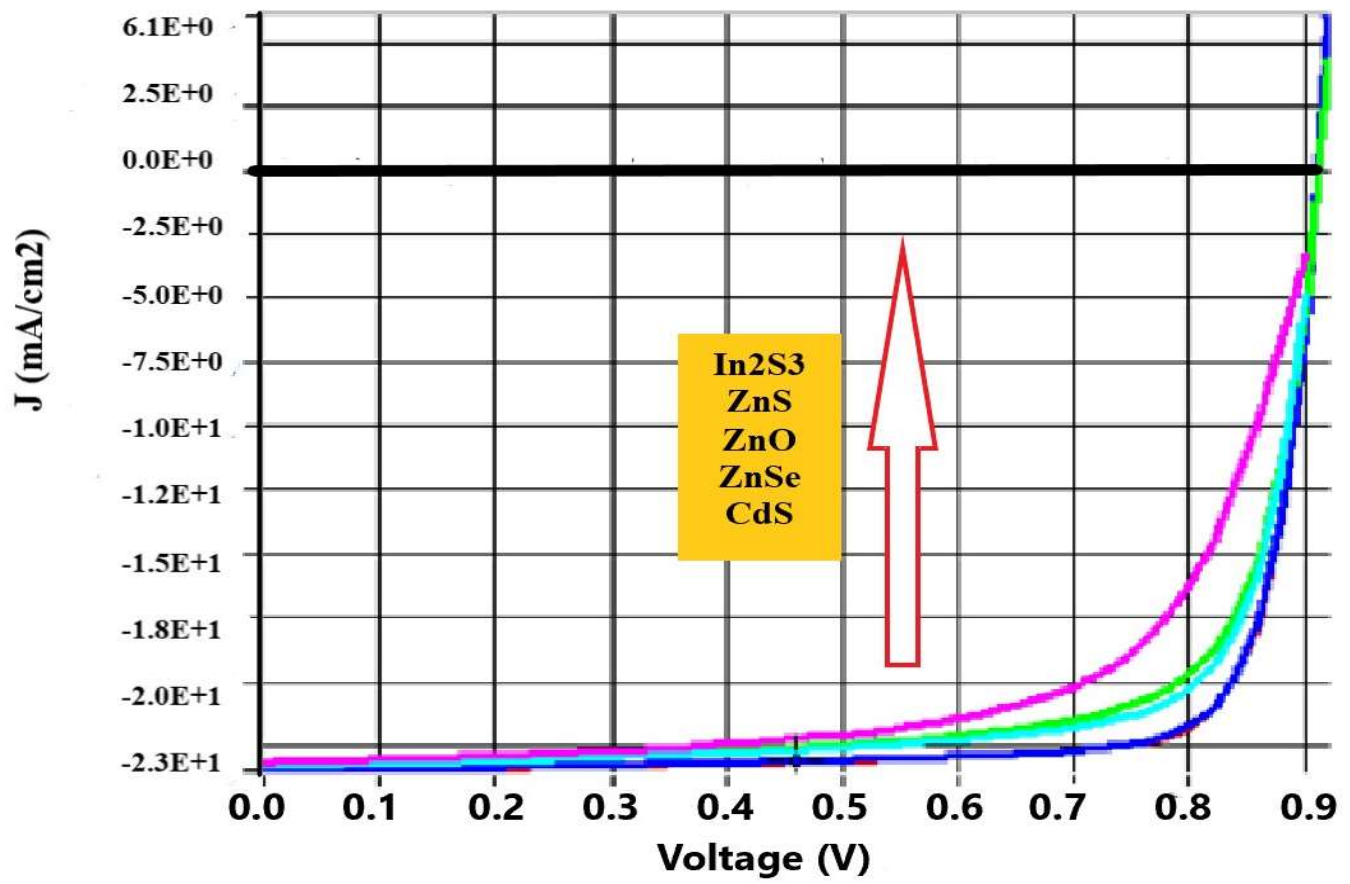

Figure 3: $J$-V current curves for the cell. CdTe layer (acceptor) with different buffer layer, at $T=300 \mathrm{~K}$

The following Eq. (5) is used to calculate the spectrum response using the external quantum efficiency:

$\operatorname{EQE}(\lambda)=\frac{I(\lambda) / q}{\varphi_{p}(\lambda)}$

Where q represents the fundamental electrical charge, $I(\lambda)$ represents photogenerated current, and $\varphi_{p}(\lambda)$ represents photon flux. On the light spectrum, Fig. 4 depicts external quantum efficiency QE \% for various buffer layers. The results reveal that when the buffer layer is CdS, the efficiency is at its peak [63]. The impact of the different buffers on the light spectrum might be seen in the Fig. 4. 


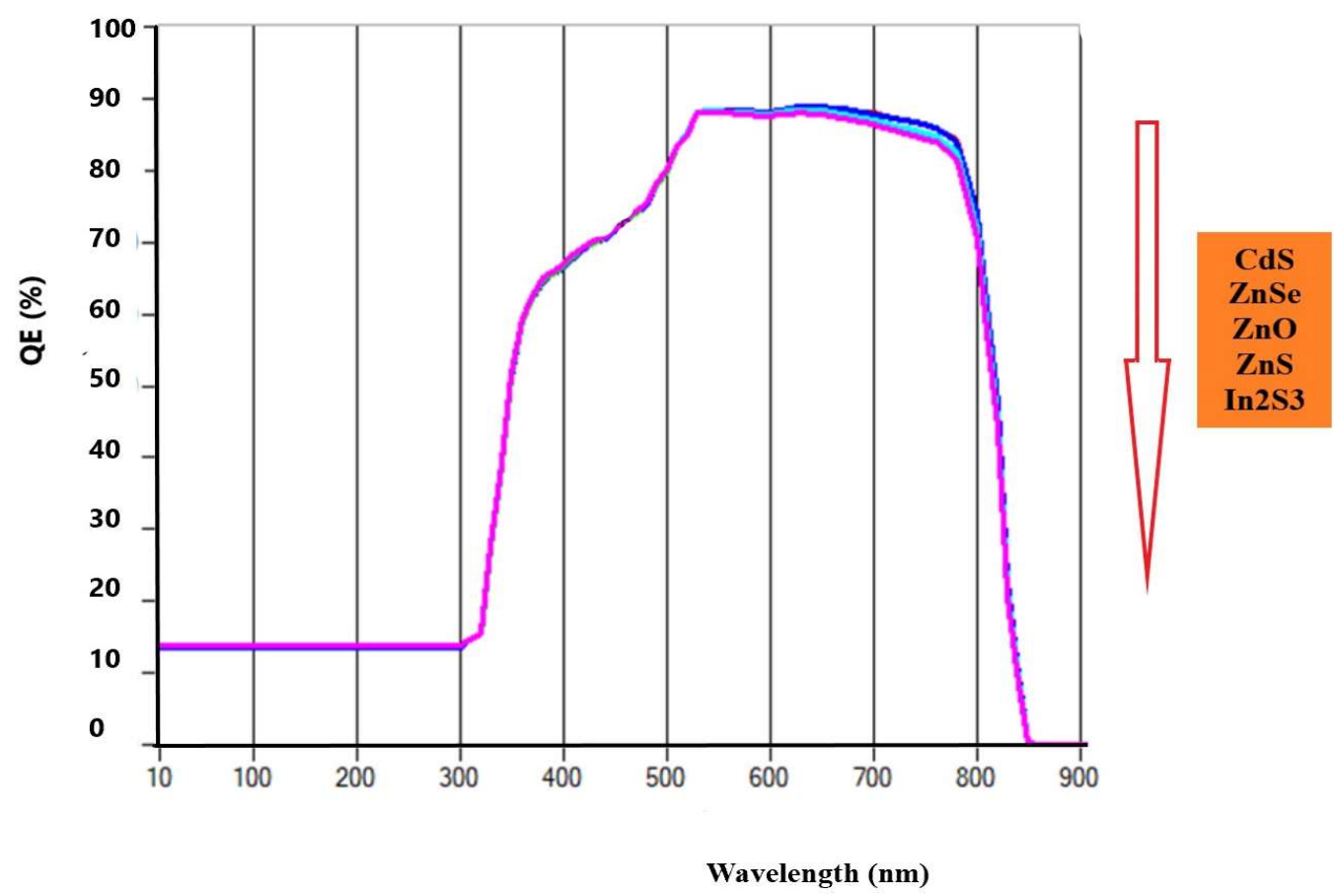

Figure 4: Spectral response of solar cells with different buffer layer, at $T=300 \mathrm{~K}$

\subsection{Modelling and optimization of CdTe absorber layer doping level}

The acceptor carrier concentration $\left(\mathrm{N}_{\mathrm{A}}\right)$ of the absorber $(\mathrm{CdTe})$ has varied between $2 \times 10^{12}$ and 2 $\mathrm{x} 10^{17}$, as indicated in Table 5. The main objective of this study is to maximize the carrier concentration $\left(\mathrm{N}_{\mathrm{A}}\right)$ of the CdTe absorber layer while maintaining cell performance.

Table 5: Effective of the acceptor carrier concentration $\left(N_{A}\right)$ on the electrical cell performance parameters, at $T=300 \mathrm{~K}$,

\begin{tabular}{lllll}
\hline $\mathbf{N}_{\mathbf{A}}\left(\mathbf{c m}^{-\mathbf{3}}\right)$ & $\mathbf{V}_{\mathbf{O C}}(\mathbf{V})$ & $\mathbf{J}_{\mathbf{S C}}\left(\mathbf{m A} \mathbf{\mathbf { c m } ^ { 2 }}\right)$ & $\mathbf{F F} \%$ & $\boldsymbol{\eta}(\%)$ \\
\hline $2 \times 10^{12}$ & 0.7333 & 24.249669 & 82.57 & 14.68 \\
$2 \times 10^{13}$ & 0.7398 & 24.248777 & 82.33 & 14.77 \\
$2 \times 10^{14}$ & 0.8263 & 24.223452 & 79.49 & 15.91 \\
$2 \times 10^{15}$ & 0.9113 & 23.484037 & 81.38 & 17.42 \\
$2 \times 10^{16}$ & 0.9662 & 21.748835 & 82.02 & 17.23 \\
$2 \times 10^{17}$ & 1.0247 & 19.810091 & 84.21 & 17.09 \\
\hline
\end{tabular}


The electrical parameter performance with acceptor (hole) carrier charge concentration $\left(\mathrm{N}_{\mathrm{A}}\right)$ at $2000 \mathrm{~nm}$ thickness of the CdTe absorber is shown in Fig. 5 (a to d). Fig. 5 (a) depicts a linear rise in open-circuit voltage $\left(V_{o c}\right)$ with $\left(N_{A}>2 \times 10^{14} \mathrm{~cm}^{-3}\right)$. Fig. 5 (b) depicts a linear reduction in short-circuit current density ( $\left.\mathrm{JSC}_{\mathrm{SC}}\right)$ with $\left(N_{A}>2 \times 10^{14} \mathrm{~cm}^{-3}\right)$, this can be ascribed to an increase in free carrier charge recombination inside the bulk [64]. On the other hand, fill factor (FF\%) as shown in Fig. 5 (c), increases linearly with $\left(N_{A}>2 \times 10^{14} \mathrm{~cm}^{-3}\right)$. Fig. 5 (d) also demonstrates that a low hole doping level $\left(N_{A}<2 \times 10^{15} \mathrm{~cm}^{-3}\right)$ leads to a significant reduction in device conversion efficiency, with values of less than $3 \%$. When the hole concentration of the absorber layer increases, however, minor cell efficiency changes are found, as shown by Eq. (6), Eq. (7), Eq. (8), and Eq. (9):

$J_{S C}=q \sum T(\lambda) \frac{\phi_{i}\left(\lambda_{i}\right)}{h v_{i}} \eta\left(\lambda_{i}\right) \Delta \lambda_{i}$

Where q denotes elementary charge, $\emptyset_{i}$ denotes spectral power density, $T(\lambda)$ denotes optical transmission, and $\Delta \lambda_{i}$ denotes the distance between two adjacent wavelength values.

$$
\begin{gathered}
V_{O C}=\frac{n k T}{q} \ln \left(\frac{J_{S C}}{J_{O}}+1\right) \\
F F \%=\frac{V_{O C}-\ln \left(V_{O C}+0.72\right)}{V_{O C}+1} \\
\eta \%=\frac{V_{O C} \times J_{S C} \times F F \%}{P_{\text {in }}}
\end{gathered}
$$

The improved efficiency (Fig. 5 (d)) in the simulated findings is explained by the combined impact of current density J SC saturation (Fig. 5 (b)), as well as the rapid increase of VoC and FF\% (Fig. 5 (a) and Fig. 5 (c)) with acceptor carrier charge concentration $\left(\mathrm{N}_{\mathrm{A}}\right)$. As a result, $\left(\mathrm{N}_{\mathrm{A}} \sim 2 \times 10^{15} \mathrm{~cm}^{-}\right.$ 3) provides the best performance for the CdTe thin film. 
(a)

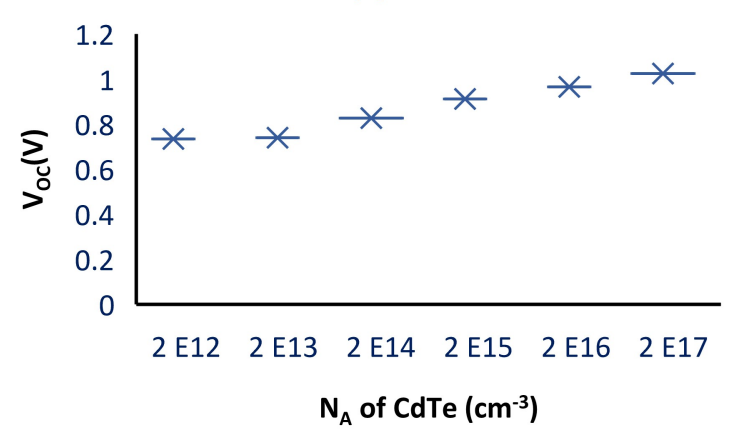

(c)

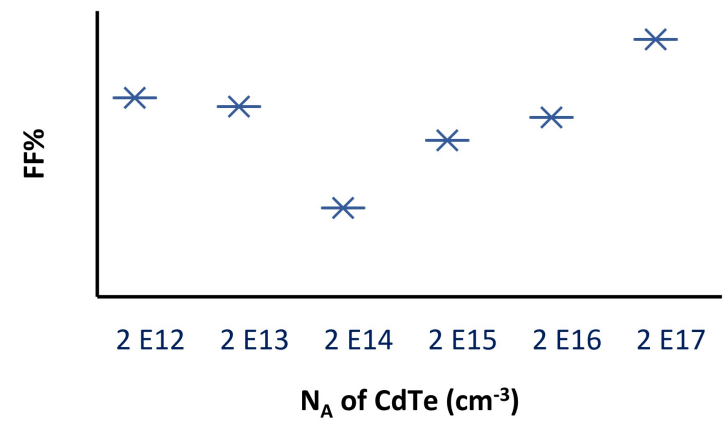

(b)

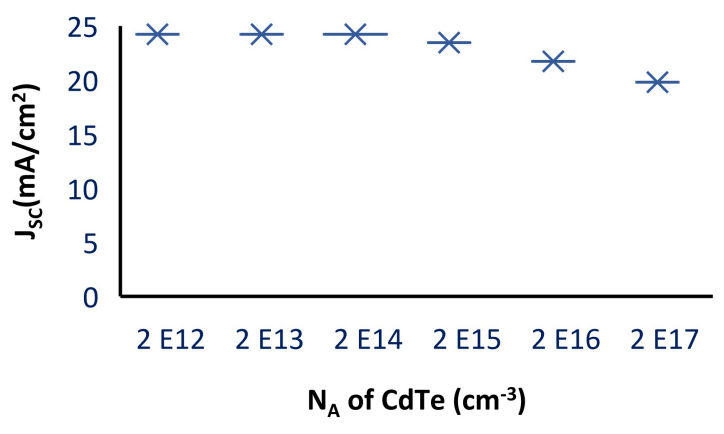

(d)

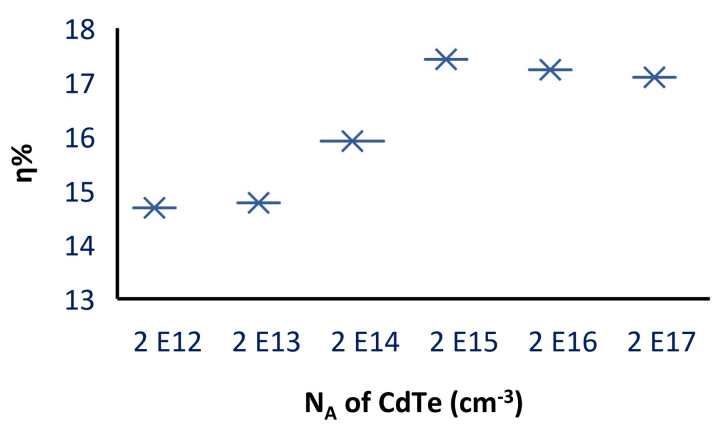

Figure 5: The simulated electrical performance parameters as a function of the acceptor charge carrier concentration $\left(N_{A}\right):(a)$. VOC. (b) $J_{S C}(c) F F \%(d) \eta \%$

The effect of changes in CdTe acceptor charge carrier concentration $\left(\mathrm{N}_{\mathrm{A}}\right)$ on solar cell fundamental characteristics was thoroughly explored. The thin film's spectral response to the CdTe acceptor carrier charge concentration $\left(\mathrm{N}_{\mathrm{A}}\right)$ (Fig. 6). The simulated findings show that when the acceptor concentration increases from $2 \times 10^{12} \mathrm{~cm}^{-3}$ to $2 \times 10^{19} \mathrm{~cm}^{-3}$., the quantum efficiency (QE\%) decreases. The enhanced gathering of photons at longer wavelengths can be ascribed to this. The production of additional pairs of electron holes in the thin-film solar cell has resulted from the absorption of longer wavelength photons, resulting in an increase in $\mathrm{J}_{\mathrm{SC}}$ at low acceptor charge carrier concentration $\left(\mathrm{N}_{\mathrm{A}}\right)$ (Fig. 7). The J-V curves show that the $\mathrm{V}_{\mathrm{OC}}$ increases as the acceptor charge carrier concentration $\left(\mathrm{N}_{\mathrm{A}}\right)$ of the CdTe layer increases $\left(N_{A}>2 \times 10^{14} \mathrm{~cm}^{-3}\right)$. This rise shows that the open-circuit voltage $\left(\mathrm{V}_{\mathrm{OC}}\right)$ of the CdTe layer is substantially influenced by the acceptor charge carrier concentration $\left(\mathrm{N}_{\mathrm{A}}\right)$. The generated electric field in the depletion region is altered when the acceptor (hole) carrier charge concentration $\left(\mathrm{N}_{\mathrm{A}}\right)$ of the CdTe layer is high [65]. As a result, the free charge carrier recombination decreased, increasing the $\mathrm{V}_{\mathrm{OC}}$. While lowering the CdTe acceptor carrier charge concentration below $2 \times 10^{15} \mathrm{~cm}^{-3}$ results in increased optical losses, which might be due to surface recombination at the back contact [66]. 


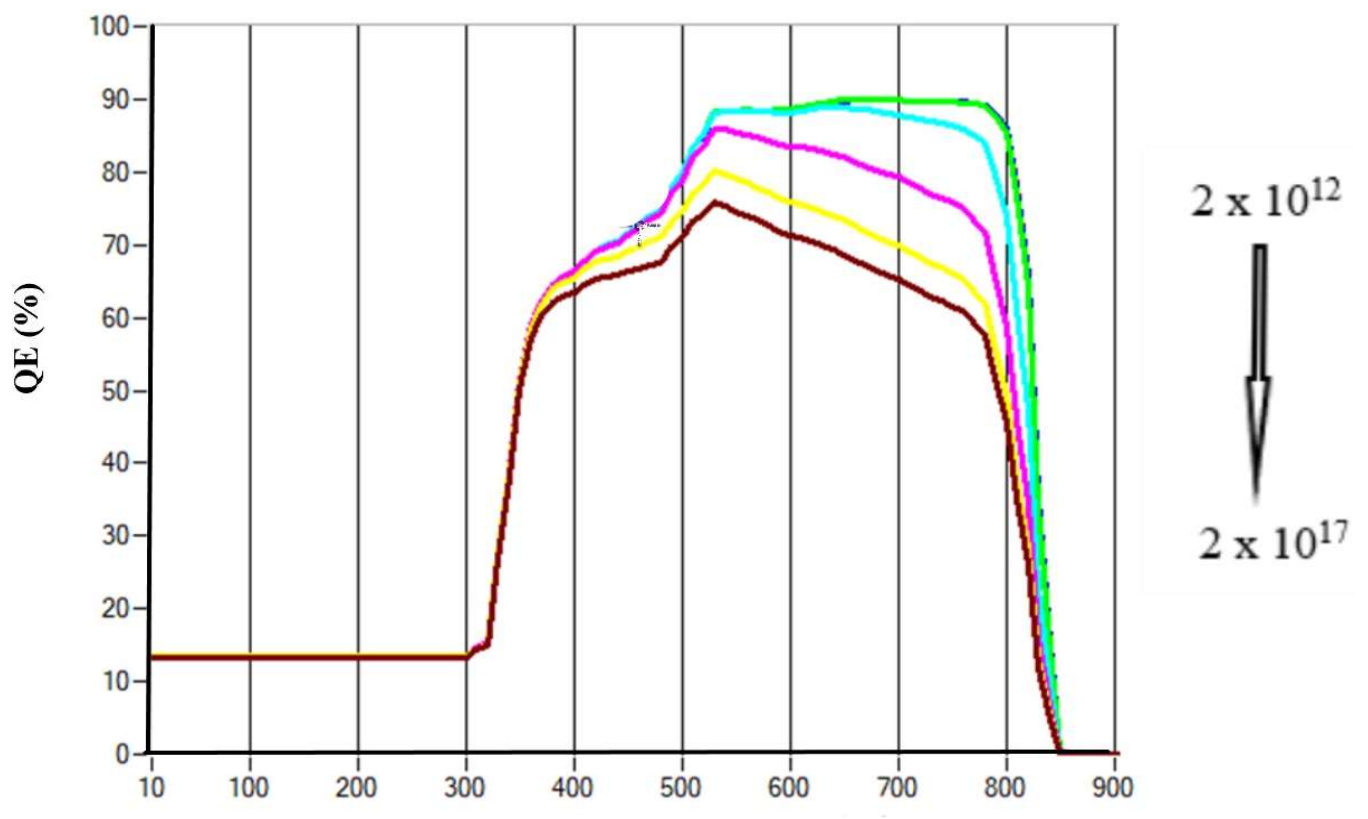

Wavelength (nm)

Figure 6: Spectral response of the enhanced quantum efficiency $(Q E)$ at longer wavelength with the increase of acceptor carrier concentration $\left(N_{A}\right)$.

The following Eq. (8) and Eq. (9) explain the PN junction model:

$$
\begin{aligned}
& I_{O}=A q n_{i}^{2}\left(\frac{D_{e}}{L_{e} N_{A}}+\frac{D_{h}}{L_{h} N_{D}}\right) \\
& V_{O C}=\frac{K T}{q \ln \left(I_{L} / I_{O}\right)}
\end{aligned}
$$

$I_{O}$ stands for saturation current, $n_{i}$ for intrinsic concentration, $A$ for diode quality factor, $q$ for elementary charge, $T$ for temperature, $k$ for Boltzmann constant, $I_{L}$ for light-generated current, $L$ and $D$ for diffusion length and coefficient, $N_{D}$ and $N_{A}$ for donor and acceptor charge concentrations. The letters $h$ and $e$ stand for holes and electrons, respectively. As the acceptor carrier concentration $\mathrm{N}_{\mathrm{A}}$ rises, the saturation current $I_{O}$ decreases, resulting in an increase in $V_{O C}$ and a drop in $\mathrm{J}_{\mathrm{SC}}$. The reason for this is that when the acceptor carrier concentration is high, the recombination process increases and reduces the probability of electron-hole production pairs, lowering the $\mathrm{QE} \%$ of long wavelength photons. Long-wavelength photons will be absorbed profoundly in the absorber (CdTe) layer [67]. 


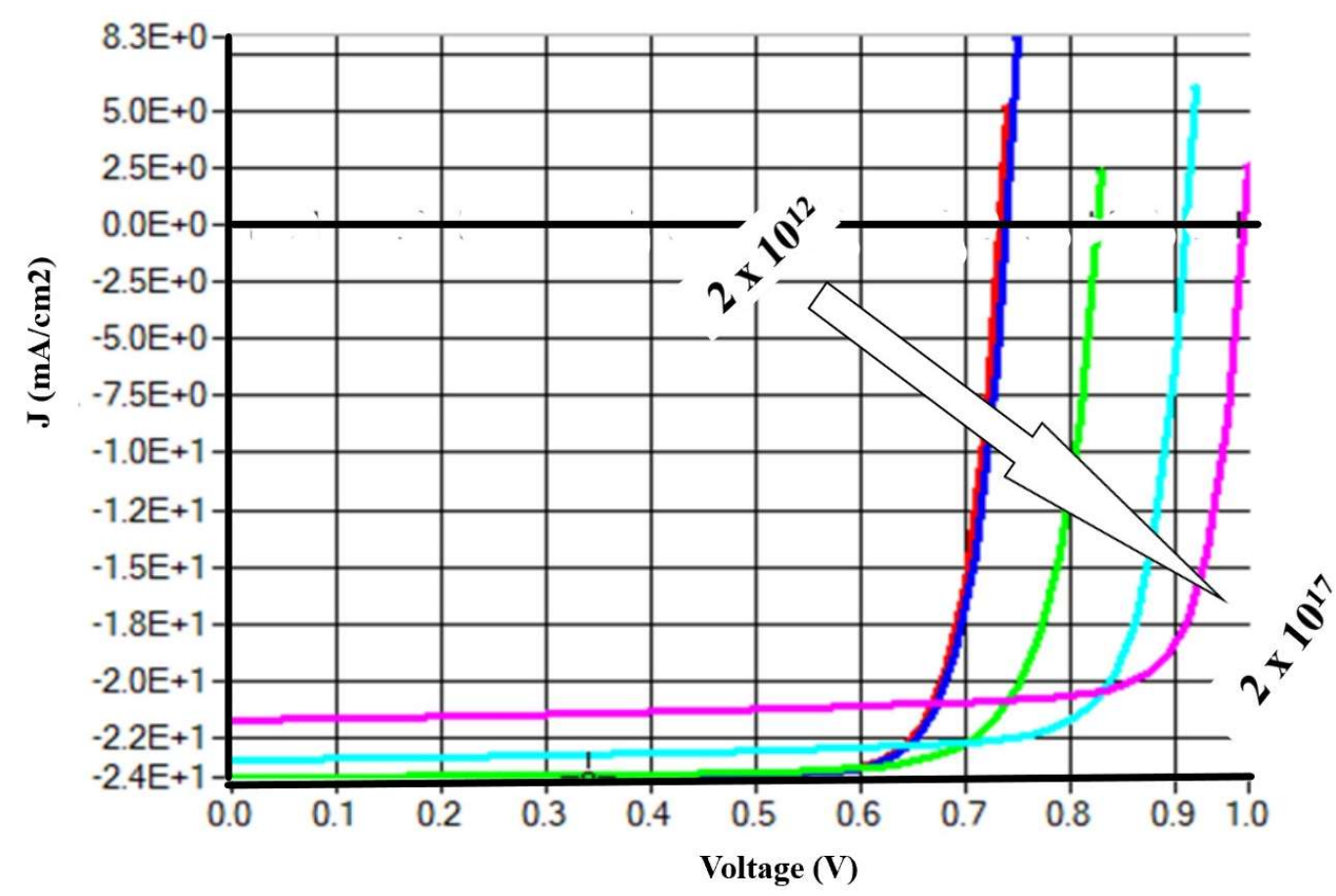

Figure 7: Short-circuit current density (Jsc) as a function of CdTe acceptor carrier concentration $\left(N_{A}\right)$.

\subsection{Modelling and optimization of ZnSe buffer layer doping level}

The major goal of this section is to decrease the buffer layer's losses (both optical and electrical). Following that, the carrier charge concentration level of the ZnSe layer was adjusted from 1 x 10 ${ }^{16} \mathrm{~cm}^{-3}$ to $1 \times 10^{22} \mathrm{~cm}^{-3}$. The effect of the ZnSe buffer on thin film performance characteristics is shown in Table 6 and Fig. 8. With $\left(N_{D}>1 \times 10^{18} \mathrm{~cm}^{-3}\right)$, the simulated results show that the modification is a tiny bit in cell performance characteristics. The effectiveness of the thin film improves by $3 \%$ when the donor concentration is increased to $\left(N_{D}=1 \times 10^{22} \mathrm{~cm}^{-3}\right)$. It is better to have a high doping level in thin film to retain its exceptional overall performance [68]. The maximum conversion efficiency is $17.42 \%$ when the donor carrier charge concentration ( $\left.N_{D} \sim 1 \times 10^{22} \mathrm{~cm}^{-3}\right)$ is used. 
Table 6: Effective of the donor charge carrier concentration $\left(N_{D}\right)$ on the electrical cell performance parameters, at $T=300 \mathrm{~K}$,

\begin{tabular}{lllll}
\hline $\mathbf{N}_{\mathbf{D}}\left(\mathbf{c m}^{-\mathbf{3}}\right)$ & $\mathbf{V}_{\mathbf{O C}}(\mathbf{V})$ & $\mathbf{J}_{\mathbf{S C}}\left(\mathbf{m A} / \mathbf{c m}^{\mathbf{2}}\right)$ & $\mathbf{F F} \%$ & $\boldsymbol{\eta} \mathbf{( \% )}$ \\
\hline $1 \times 10^{16}$ & 0.9178 & 23.275532 & 67.7 & 14.46 \\
$1 \times 10^{17}$ & 0.918 & 23.25272 & 68.22 & 14.57 \\
$1 \times 10^{18}$ & 0.9103 & 23.33507 & 78.62 & 16.7 \\
$1 \times 10^{19}$ & 0.9111 & 23.419193 & 80.54 & 17.19 \\
$1 \times 10^{20}$ & 0.9112 & 23.453013 & 81.07 & 17.33 \\
$1 \times 10^{21}$ & 0.9113 & 23.474864 & 81.29 & 17.39 \\
$1 \times 10^{22}$ & 0.9113 & 23.484037 & 81.38 & 17.42 \\
\hline
\end{tabular}

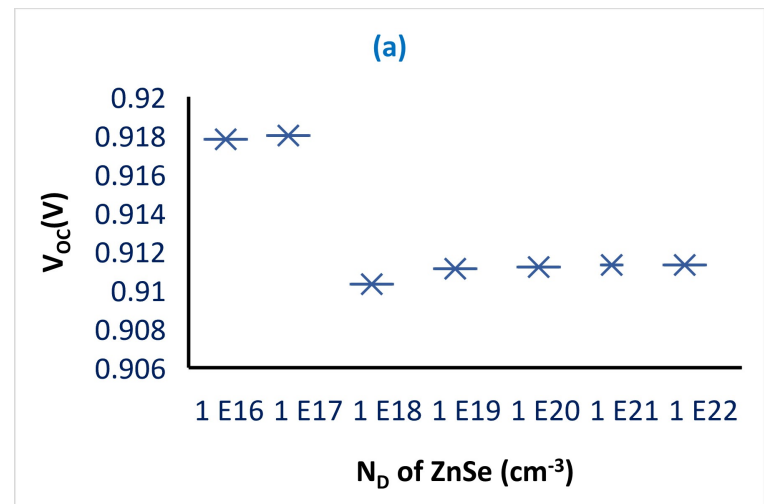

(c)

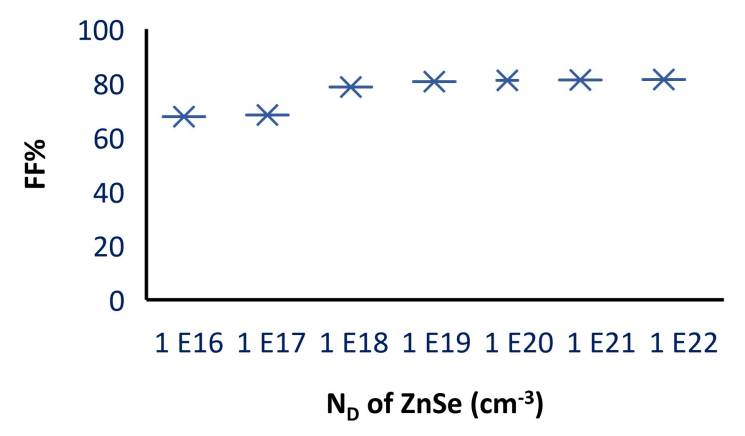

(b)

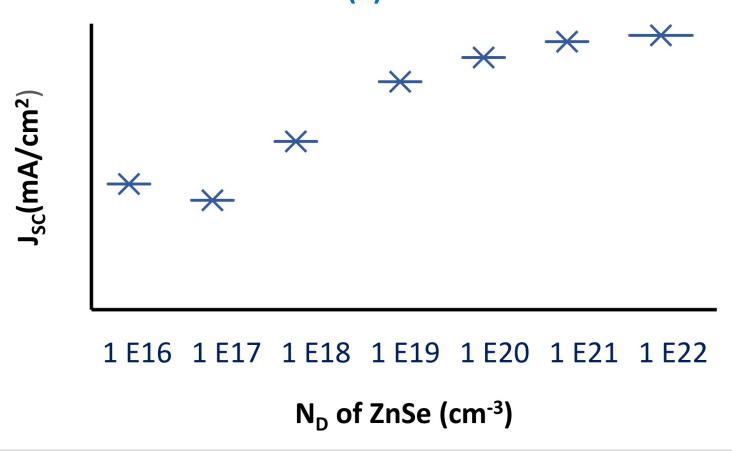

(d)

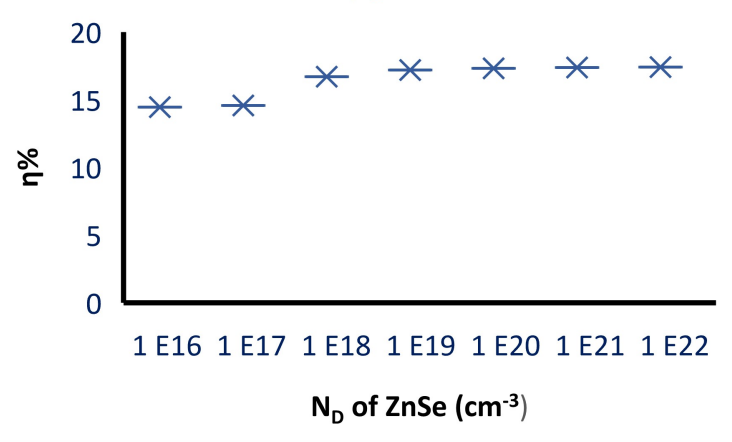

Figure 8: The simulated electrical performance parameters as a function of donor charge carrier concentration (ND): (a) $V_{O C}(b) J_{S C}(c) F F \%(d) \eta \%$

Figure 8 ( $a$ to d) illustrates how a high donor concentration in the buffer layer improves cell performance. This is owing to the apparent requirement for a minimum buffer layer thickness to compensate for the dislocation effect caused by the grid mismatch between the ZnSe and CdTe layers. Although the $J_{S C}, F F \%$ and $\eta \%$ parameters all rise (Fig. 8 (b-d)), the $V_{O C}$ drops (Fig. 8 (a)). 
The explanation for this may be ascribed to photon loss on a large buffer layer, as seen in Fig. 9. As the concentration of the buffer layer $\left(\mathrm{N}_{\mathrm{D}}\right)$ decreases, more incident photons generated by the ZnSe layer are absorbed, reducing the number of photons that the absorber (CdTe) layer can absorb. As illustrated in Fig. 10, absorbed photons generate fewer electron-hole pairs, resulting in a lower $\mathrm{QE} \%$. As the donor carrier charge concentrations increase, so does the QE \%. In the simulation, it is better to have a high buffer layer donor concentration $\left(N_{D}>1 \times 10^{18} \mathrm{~cm}^{-3}\right)$ for thin films.

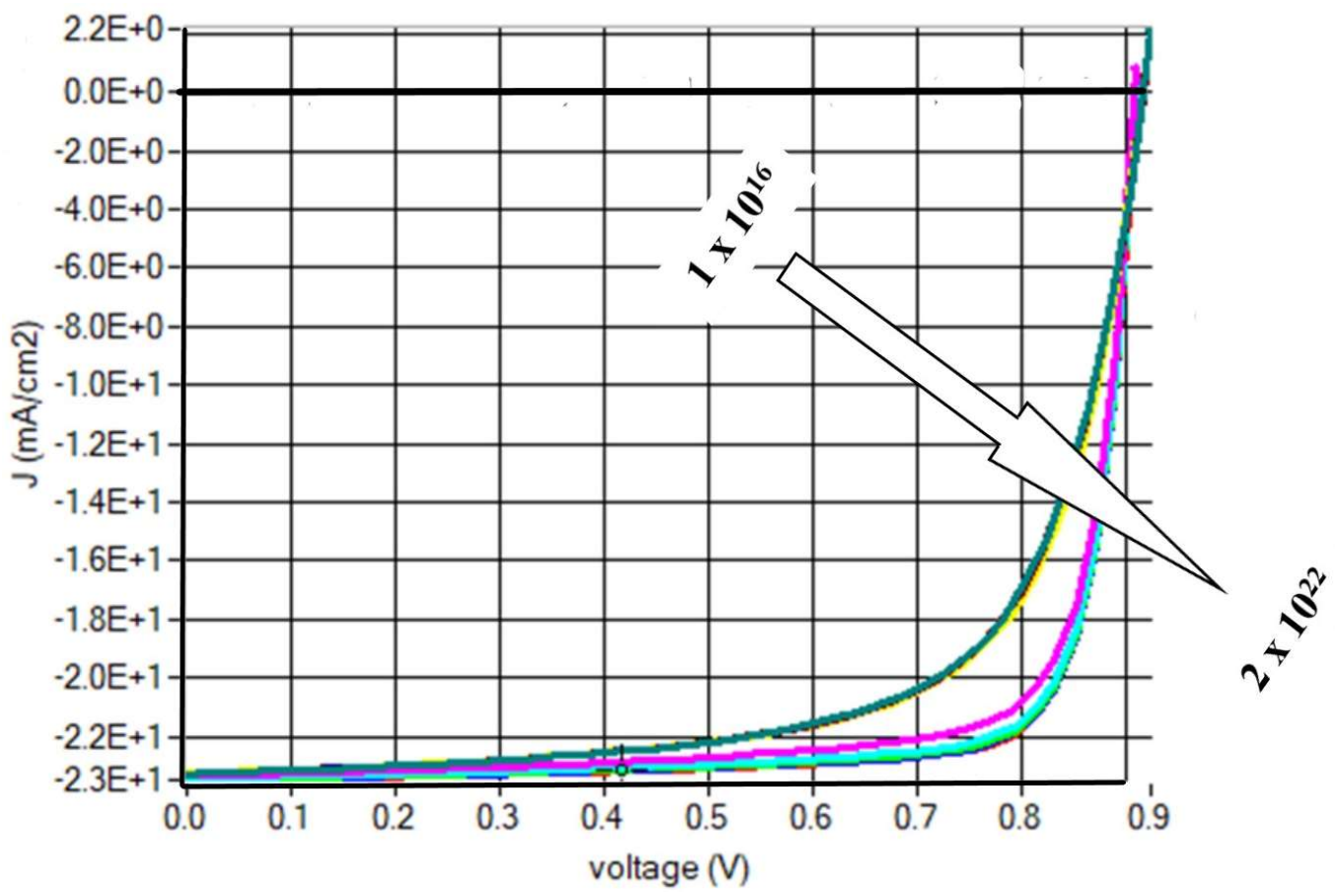

Figure 9: J-V as a function of ZnSe donner carrier concentration $\left(N_{D}\right)$. 


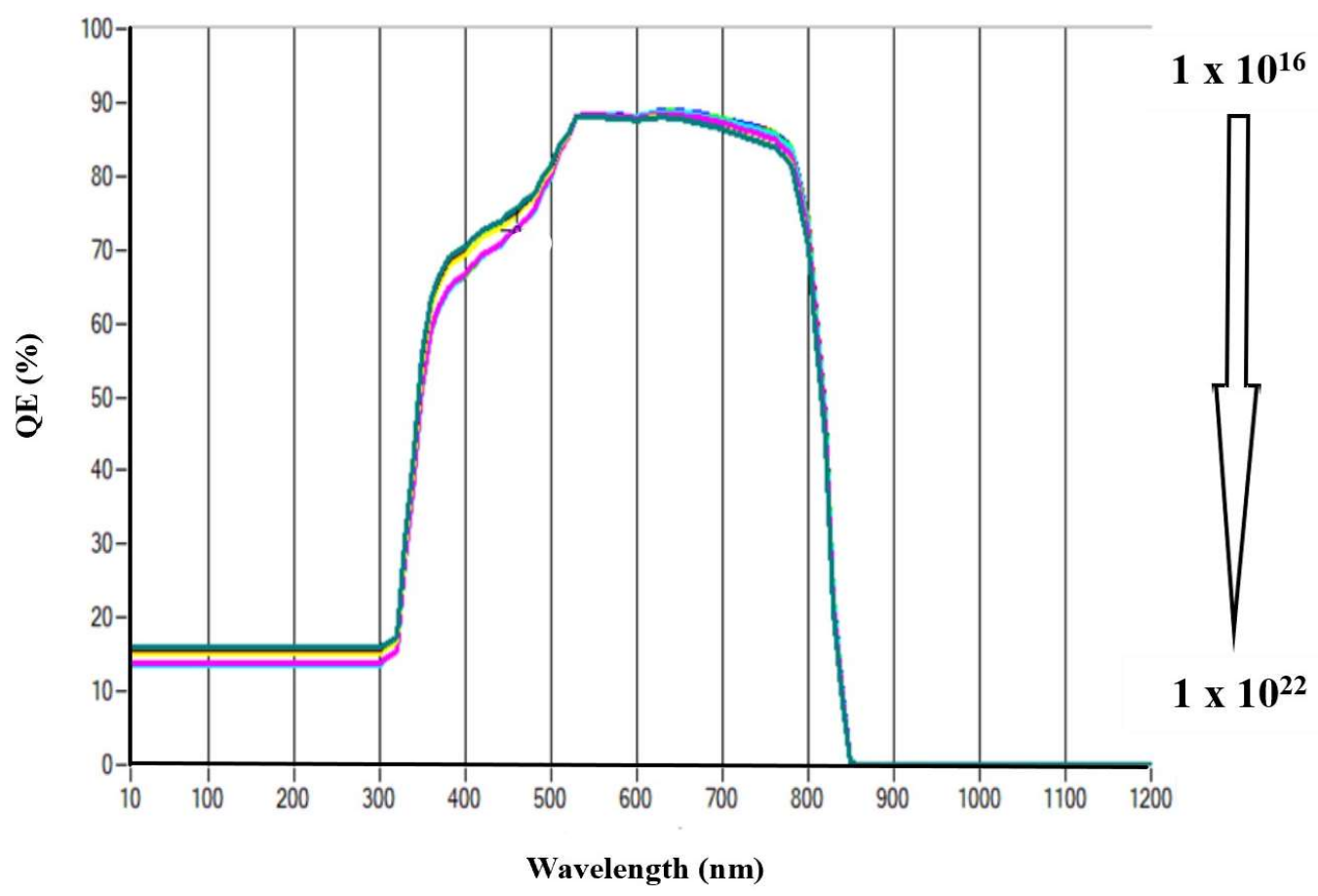

Figure 10: Spectral response of the enhanced quantum efficiency $(Q E)$ at longer wavelength with the increase of donner carrier concentration $\left(N_{D}\right)$.

\subsection{Optimization of the $\mathrm{Mo} / \mathrm{CdTe} / \mathrm{ZnSe} / \mathrm{SnO}_{2}$ thin film-based solar cell}

Based on the simulation results described above in the specified parameter range, optimum PV characteristics can be achieved with an efficiency of $17.42 \%$ (with $\mathrm{V}_{\mathrm{OC}}=0.9113 \mathrm{~V}, \mathrm{~J}_{\mathrm{SC}}=$ $23.484037 \mathrm{~mA} / \mathrm{cm}^{2}$, and $\mathrm{FF} \%=81.38 \%$ ), when the thickness and acceptor concentration of the CdTe are $2000 \mathrm{~nm}$ and $2 \times 10^{15} \mathrm{~cm}^{-3}$, respectively, thickness and donor concentration of the ZnSe are $25 \mathrm{~nm}$ and $1 \times 10^{22} \mathrm{~cm}^{-3}$, and thickness and donor concentration of the $\mathrm{SnO}_{2}$ are $250 \mathrm{~nm}$ and 1 $\times 10^{22} \mathrm{~cm}^{-3}$ respectively. Other electrical and optical parameters of the thin film are unchanged, as shown in Table1.

\subsubsection{Band diagram:}

One of the most notable factors impacting thin film performance and current transmission across heterojunctions is band alignment. Fig. 11 illustrates our findings. There is a good band, as can be seen. CdTe is used as the absorber layer, with $\mathrm{ZnSe}$ as the buffer layer and $\mathrm{SnO}_{2}$ as the window layer. Fig. 11. shows the CdTe absorber layer from 0 to $2 \mu \mathrm{m}$, the ZnSe buffer layer from $2 \mu \mathrm{m}$ to $2.025 \mu \mathrm{m}$, and the $\mathrm{SnO}_{2}$ window layer from $2.025 \mu \mathrm{m}$ to $2.275 \mu \mathrm{m}$. When the absorber layer's conduction band is higher than the buffer layer's conduction band, the result is a "cliff" type band 
alignment [69]. As seen in Fig. 11, this is the situation with CdTe thin films. It can be shown that the absorber, buffer, and window layers have acceptable band alignment. Four recombination regions may be seen in the band diagram.

(a)

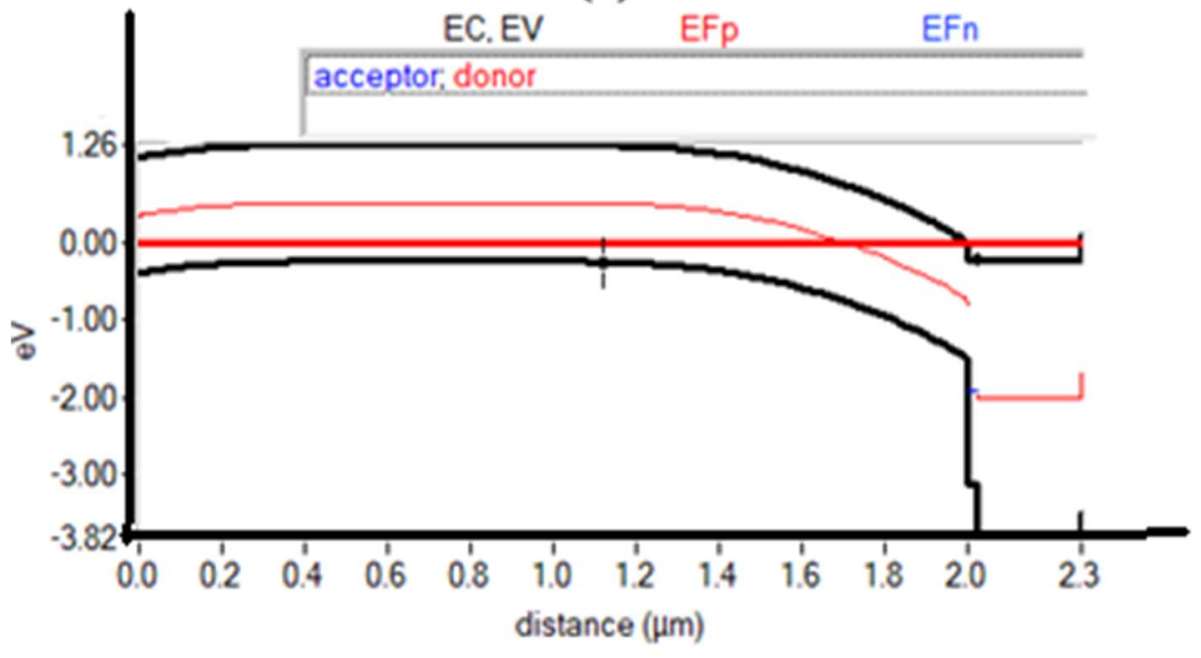

(b)

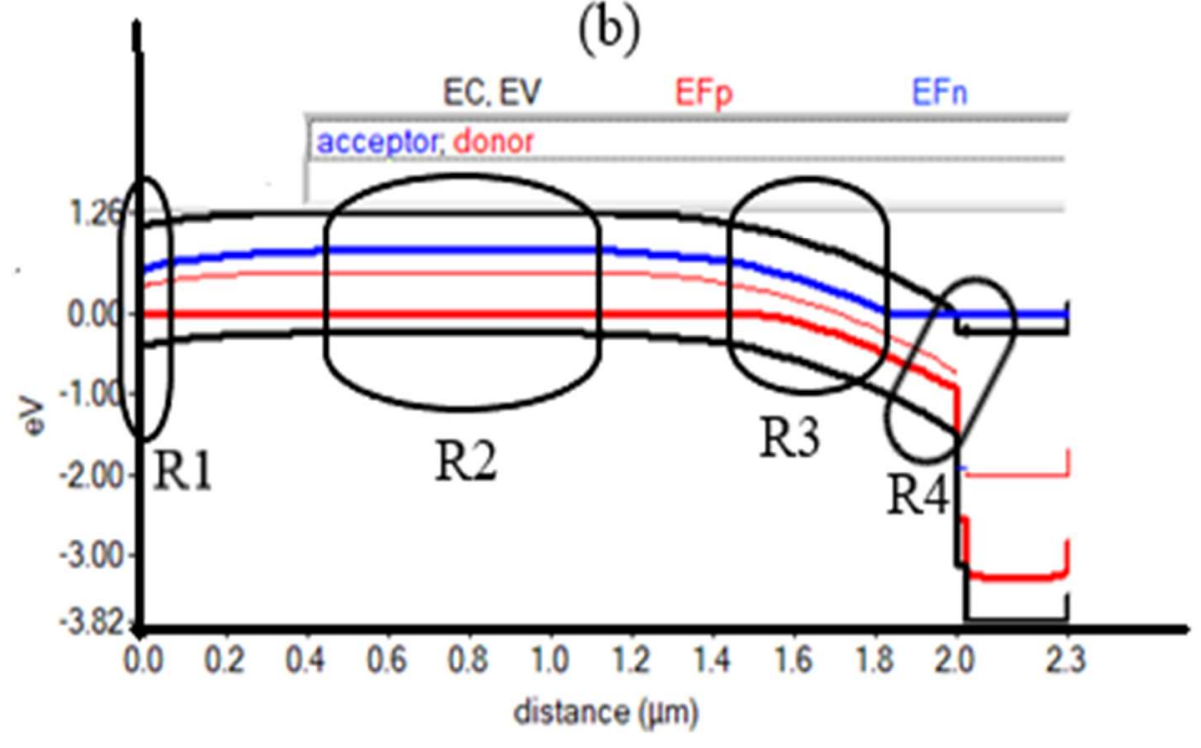

Figure 11: The band Energy diagram CdTe layer (acceptor). ZnSe layer (buffer), and SnO layer (window (a) Dark current, (b) Photo Current

Recombination at the back contact (region R1), bulk (Quasi-Neutral) recombination in the absorber layer (region R2), space charge (region R3), and recombination at the absorber/buffer interface (region R4) are the four regions. The thin absorber layer will maintain the back-contact 
close to the depletion region, resulting in a substantial increase in back contact recombination. Reasonable neutral interface defects for recombination were also included at the mid-gap to accommodate for recombination at the $\mathrm{CdTe} / \mathrm{CdS}$ and $\mathrm{ZnSe} / \mathrm{SnO}_{2}$ interfaces [70]. The reflectance of the rear and front contact surfaces was adjusted to 0.1 and 0.9 , respectively (Table 3 ). Photons that traverse the absorber are reflected by this high reflectivity upon return contact, which improves absorption in the absorber.

\subsubsection{Current mode:}

The cross-over and roll-over of the J-V curves are J-V characteristics of the Mo / CdTe / ZnSe / $\mathrm{SnO}_{2}$ thin film. The intersection of dark and illuminated $\mathrm{J}-\mathrm{V}$ curves is known as a cross-over. The phenomenon of roll-over occurs when the J-V curve is meshed, and current levels of greater voltage are present. The dark and photo J-V curves are depicted in Figure 12. The ideal layer carrier concentration densities in SCAPS-1D's computation $\left(\mathrm{CdTe} \mathrm{N}_{\mathrm{A}}=2 \times 10^{15} \mathrm{~cm}^{-3}, \mathrm{ZnSe} \mathrm{N}_{\mathrm{D}}=\right.$ $1 \times 10^{22} \mathrm{~cm}^{-3}$, and $\mathrm{SnO}_{2} \mathrm{~N}_{\mathrm{D}}=1 \times 10^{22} \mathrm{~cm}^{-3}$ ) are used in the simulation. Figure 12 shows the output cell efficiency parameters. The carrier concentration of the absorber layer / buffer layer interface recombination or the absorber/back contact was measured using this advantage [71].

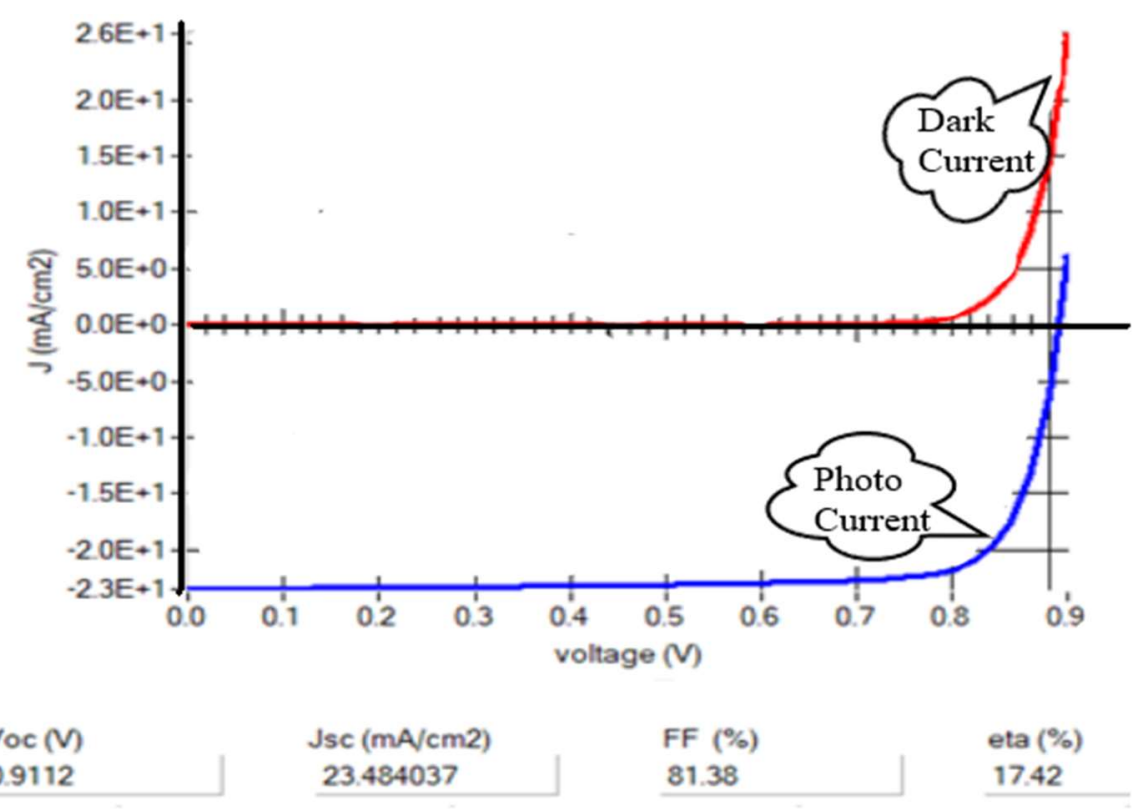

Figure 12: Current density with voltage, at $T=300 \mathrm{~K},\left(\mathrm{CdTe} \mathrm{N}_{\mathrm{A}}=2 \times 10^{15} \mathrm{~cm}^{-3}\right.$, $\mathrm{ZnSe} \mathrm{ND}_{\mathrm{D}}=1 \times 10^{22} \mathrm{~cm}^{-3}$, and $\left.\mathrm{SnO}_{2} \mathrm{~N}_{\mathrm{D}}=1 \times 10^{22} \mathrm{~cm}^{-3}\right)$ 


\subsubsection{Quantum Efficiency (QE\%):}

The optimal QE\% for the thin film is shown in Fig. 13. The ratio of the number of captured electrons to the number of incident photons on the solar cell is known as the QE\%. The QE\% will be $100 \%$ when all of the carriers have been gathered and all of the photons have been absorbed by CdTe. Photons $\left(h v \geq E_{g}\right)$. are absorbed by the absorber layer. Because the absorption layer cannot absorb low-energy photons, high-energy photons are able to contribute to the thermalization process, resulting in a variety of losses such as shading losses, spectral mismatch losses, shading losses, incomplete absorption, and collection losses, all of which reduce quantum efficiency [67].

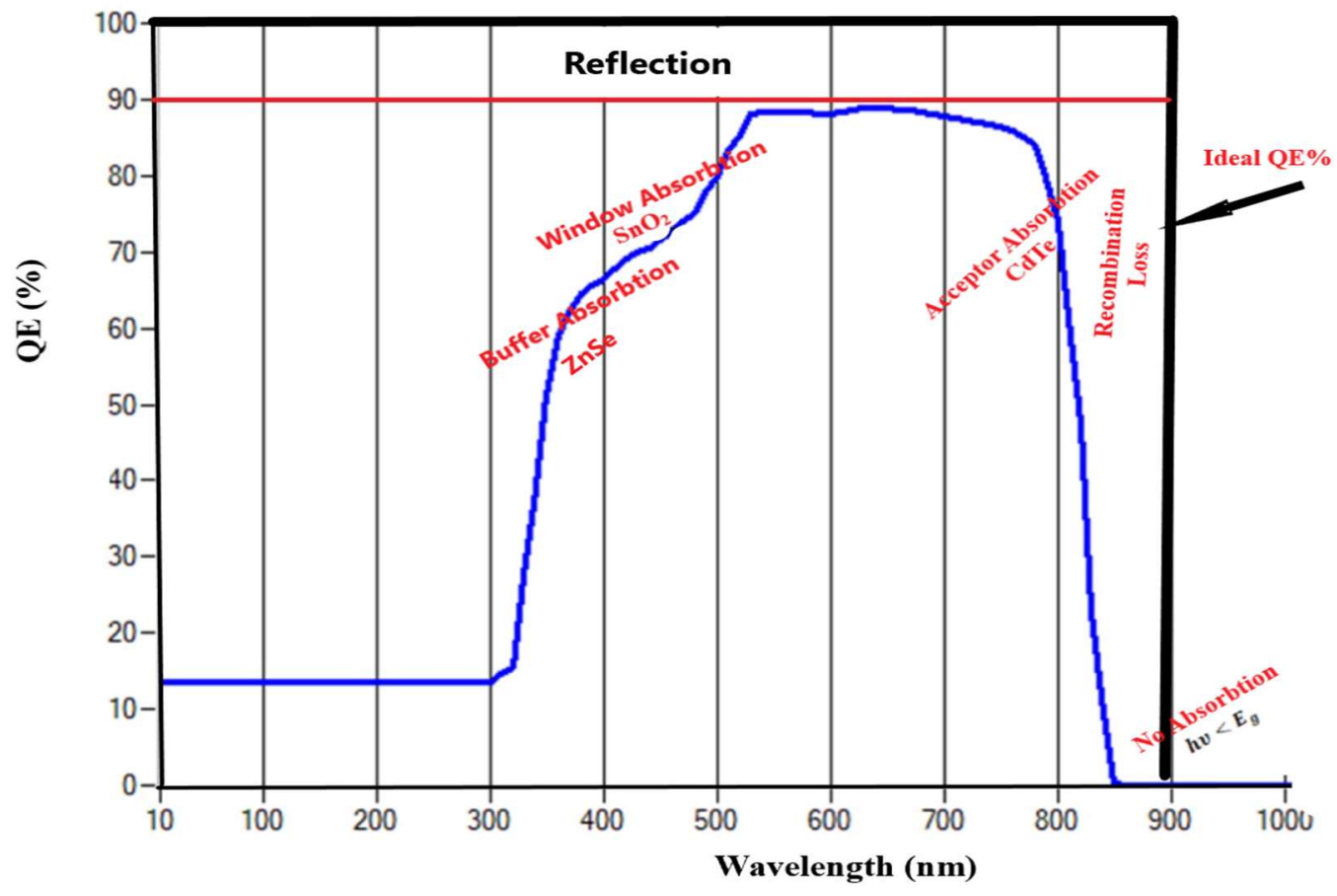

Figure 13: Quantum Efficiency (QE\%) outputs for the thin film $\left(\mathrm{CdTe} \mathrm{N}_{\mathrm{A}}=2 \times 10^{15} \mathrm{~cm}^{-3}, \mathrm{ZnSe} \mathrm{N_{ \textrm {D } }}=1 \times 10^{22} \mathrm{~cm}^{-3}\right.$, and $\mathrm{SnO}_{2} \mathrm{~N}_{\mathrm{D}}=1 \times 10^{22} \mathrm{~cm}^{-3}$ ), at $T=300 \mathrm{~K}$,

$$
\boldsymbol{h v}<\boldsymbol{E}_{\boldsymbol{g}}
$$

\subsubsection{Effect of Transparent Conducting layer (window layer)}

Both optical and electrical access are provided by transparent conducting oxide (TCO) layers. $\mathrm{SnO}_{2}$ was employed as the TCO in our situation. $\mathrm{SnO}_{2}$ has a bandgap of $3.6 \mathrm{eV}$, which is sufficient to cover the whole visible wavelength range. $\mathrm{SnO}_{2}$ has a thickness of $250 \mathrm{~nm}$ and a donor concentration of $1 \times 10^{22} \mathrm{~cm}^{-3}$, respectively. The window layer contributes a little to the production of electron-hole pairs. 


\subsection{Comparison between recent published work and proposed work}

Table 7 shows that the proposed work outperforms the recent published studies in terms of open circuit voltage $\left(\mathrm{V}_{\mathrm{OC}}\right)$, shot circuit current $\left(J_{S C}\right)$, and conversion efficiency $(\eta \%)$ of the cell construction. The proposed cell structure Glass/Mo/CdTe/ZnSe/SnO ${ }_{2}$ outperforms others due to high $J_{S C}$ and $\mathrm{V}_{\mathrm{OC}}$, which result in higher conversion efficiency. The low FF value might be related to defect states in any of the device's layers. If the proposed cell structure can be effectively manufactured, this design method will become the superior option.

Table7: Comparison of functional parameters with experimental result

\begin{tabular}{|c|c|c|c|c|c|c|}
\hline \multicolumn{2}{|c|}{ Buffer } & $V_{\text {oc }}(\mathrm{V})$ & $\mathrm{J}_{\mathrm{SC}}\left(\mathrm{mA} / \mathrm{cm}^{2}\right)$ & FF & $\eta$ & Ref., Year \\
\hline CdS & Experimental /CBD & 0.69 & 30.9 & 72 & 15.3 & {$[72]$} \\
\hline & Simulated/ SCAPS-1D & 0.9113 & 23.4497335 & 81.41 & 17.43 & Propose Work \\
\hline ZnSe & Experimental/CBD & 0.67 & 34.9 & 72.7 & 14.4 & [73] \\
\hline & Simulated/ SCAPS-1D & 0.9112 & 23.484037 & 82.38 & 17.42 & Propose Work \\
\hline $\mathrm{ZnS}$ & Experimental/CBD & 0.55 & 34.4 & 73 & 13.6 & {$[73]$} \\
\hline & Simulated/ SCAPS-1D & 0.9121 & 23.260166 & 74.84 & 15.88 & Propose Work \\
\hline $\mathbf{I n}_{2} \mathrm{~S}_{3}$ & Experimental / ALCVD & 0.27 & 46.8 & 71.5 & 12.9 & [74] \\
\hline & Simulated/ SCAPS-1D & 0.9198 & 23.153579 & 66.81 & 14.23 & Propose Work \\
\hline ZnO & Experimental /CBD & 0.835 & 24.1 & 75.46 & 15.19 & {$[75]$} \\
\hline & Simulated/ SCAPS-1D & 0.9142 & 23.303926 & 76.37 & 16.27 & Propose Work \\
\hline
\end{tabular}

\section{Conclusions}

In this article, from a numerical simulation standpoint, it employs several buffer layers (CdS, $\mathrm{ZnSe}$, $\mathrm{ZnS}, \mathrm{In}_{2} \mathrm{~S}_{3}, \mathrm{ZnO}$ ), and the outcome indicates that $\mathrm{CdS}$ is the best buffer layer. Thus, it can be stated that $\mathrm{ZnSe}$ and $\mathrm{ZnO}$ are a good option as an alternate buffer layer to the $\mathrm{CdS}$ of CdTe solar cells, considering the findings from the simulation using SSAPS-1D. Also, the appropriate material for the CdS buffer layer must be changed. Furthermore, numerical simulation analysis has shown that the rise in $\mathrm{N}_{\mathrm{A}}$ and $\mathrm{N}_{\mathrm{D}}$ results in an increase in solar cell performance. The effect on cell performance was also studied via the ZnSe buffer layer. Our analysis also showed that it can be obtained at a value of $\eta \%$ of $17.42 \%$ (with $\mathrm{J}_{\mathrm{SC}}=23.484037 \mathrm{~mA} / \mathrm{cm}^{2}, \mathrm{~V}_{\mathrm{OC}}=0.9113 \mathrm{~V}$, and $\mathrm{FF} \%=$ $81.38 \%$ ) for a $2000 \mathrm{~nm}$ thick CdTe absorber layer with $\mathrm{N}_{\mathrm{A}} \sim 2 \times 10^{15} \mathrm{~cm}^{-3}, 25 \mathrm{~nm}$ thick ZnSe buffer layer with $\mathrm{N}_{\mathrm{D}} \sim 1 \times 10^{22} \mathrm{~cm}^{-3}$, and $250 \mathrm{~nm}$ thick $\mathrm{SnO}_{2}$ window layer with $\mathrm{N}_{\mathrm{D}} \sim 1 \times 10^{22} \mathrm{~cm}^{-3}$. While these results may enable us to make the requested CdTe thin film solar cell, certain other effective factors have to be investigated in further studies that may influence cell perform. 
Acknowledgments: The authors would like to acknowledge the University of Gent, Belgium for providing the SCAPS simulator. Furthermore, we are grateful to Ajman University for supporting this study.

\section{References}

[1] C.N. Kruse, S. Schäfer, F. Haase, V. Mertens, H. Schulte-Huxel, B. Lim, B. Min, T. Dullweber, R. Peibst, R. Brendel, Simulation-based roadmap for the integration of poly-silicon on oxide contacts into screenprinted crystalline silicon solar cells, Scientific Reports, 11 (2021) 1-14.

[2] S. Zhuk, A. Kushwaha, T.K. Wong, S. Masudy-Panah, A. Smirnov, G.K. Dalapati, Critical review on sputter-deposited Cu2ZnSnS4 (CZTS) based thin film photovoltaic technology focusing on device architecture and absorber quality on the solar cells performance, Solar Energy Materials and Solar Cells, 171 (2017) 239-252.

[3] A.S. Najm, N.A. Ludin, M.F. Abdullah, M.A. Almessiere, N.M. Ahmed, M.A. Al-Alwani, Areca catechu extracted natural new sensitizer for dye-sensitized solar cell: Performance evaluation, Journal of Materials Science: Materials in Electronics, 31 (2020) 3564-3575.

[4] A. Arce-Plaza, F. Sánchez-Rodriguez, M. Courel-Piedrahita, O.V. Galán, V. Hernandez-Calderon, S. Ramirez-Velasco, M.O. López, CdTe thin films: deposition techniques and applications, Coatings and ThinFilm Technologies, (2018) 131-148.

[5] K. Gutierrez ZB, P. G Zayas-Bazán, O. De Melo, D. Moure-Flores, J.A. Andraca-Adame, L. Moreno-Ruiz, H. Martínez-Gutiérrez, S. Gallardo, J. Sastré-Hernández, G. Contreras-Puente, CdS/CdTe heterostructures for applications in ultra-thin solar cells, Materials, 11 (2018) 1788.

[6] G.L. Maxwell, Characterization and modeling of $\mathrm{CdCl} 2$ treated $\mathrm{CdTe} / \mathrm{CdS}$ thin-film solar cells, in, Colorado State University. Libraries, 2010.

[7] D. Kwon, Studies of Sputtered Cadmium Telluride and Cadmium Selenide Solar Cells, in, The University of Toledo, 2012.

[8] K.-J. Hsiao, Electron-reflector strategy for CdTe thin-film solar cells, Colorado State University, (2010).

[9] K. Emery, Y. Hishikawa, W. Warta, E. Dunlop, D. Levi, A. Ho-Baillie, Solar cell efficiency tables (Version 46), in: Mat. Res. Soc, 2015, pp. 231-234.

[10] M. Bouroushian, Electrochemistry of the Chalcogens, in: Electrochemistry of metal chalcogenides, Springer, 2010, pp. 57-75.

[11] A. Bouloufa, K. Djessas, A. Zegadi, Numerical simulation of CulnxGa1- xSe2 solar cells by AMPS-1D, Thin Solid Films, 515 (2007) 6285-6287.

[12] Y. Guo, X. Deng, Electrodeposition of CdTe thin films and their photoelectrochemical behaviour, Solar energy materials and solar cells, 29 (1993) 115-122.

[13] J. Su, T. Minegishi, M. Katayama, K. Domen, Photoelectrochemical hydrogen evolution from water on a surface modified CdTe thin film electrode under simulated sunlight, Journal of Materials Chemistry A, 5 (2017) 4486-4492.

[14] O. Echendu, K. Okeoma, C. Oriaku, I. Dharmadasa, Electrochemical deposition of CdTe semiconductor thin films for solar cell application using two-electrode and three-electrode configurations: A comparative study, Advances in Materials Science and Engineering, 2016 (2016).

[15] V. Nikale, S. Shinde, C. Bhosale, K. Rajpure, Physical properties of spray deposited CdTe thin films: PEC performance, Journal of Semiconductors, 32 (2011) 033001.

[16] N.A. Abdul-Manaf, H.I. Salim, M.L. Madugu, O.I. Olusola, I.M. Dharmadasa, Electro-plating and characterisation of $\mathrm{CdTe}$ thin films using $\mathrm{CdCl} 2$ as the cadmium source, Energies, 8 (2015) 10883-10903.

[17] H. Salim, V. Patel, A. Abbas, J. Walls, I. Dharmadasa, Electrodeposition of CdTe thin films using nitrate precursor for applications in solar cells, Journal of Materials Science: Materials in Electronics, 26 (2015) 3119-3128. 
[18] A. Ojo, I. Dharmadasa, Analysis of electrodeposited CdTe thin films grown using cadmium chloride precursor for applications in solar cells, Journal of Materials Science: Materials in Electronics, 28 (2017) 14110-14120.

[19] M. Greenu, K. Emery, Y. Hishikawa, W. Warta, E. Dunlop, Solar cell efficiency tables (version 46), Prog. Photovoltaic: Res Appl, 23 (2015) 805-812.

[20] Y. Kwon, J. Seo, Y. Kang, D. Kim, J. Kim, Bifacial CdS/CdTe thin-film solar cells using a transparent silver nanowire/indium tin oxide back contact, Optics express, 26 (2018) A30-A38.

[21] A.M. Holi, A.A. Al-Zahrani, A.S. Najm, P. Chelvanathan, N. Amin, PbS/CdS/ZnO nanowire arrays: Synthesis, structural, optical, electrical, and photoelectrochemical properties, Chemical Physics Letters, 750 (2020) 137486.

[22] A.S. Najm, P. Chelvanathan, S.K. Tiong, M.T. Ferdaous, S.A. Shahahmadi, Y. Yusoff, K. Sopian, N. Amin, Numerical Insights into the Influence of Electrical Properties of $n$-CdS Buffer Layer on the Performance of SLG/Mo/p-Absorber/n-CdS/n-ZnO/Ag Configured Thin Film Photovoltaic Devices, Coatings, 11 (2021) 52.

[23] A. Voznyi, V. Kosyak, A. Opanasyuk, N. Tirkusova, L. Grase, A. Medvids, G. Mezinskis, Structural and electrical properties of SnS2 thin films, Materials Chemistry and Physics, 173 (2016) 52-61.

[24] X. Zheng, W. Li, A.G. Aberle, S. Venkataraj, Efficiency enhancement of ultra-thin Cu (In, Ga) Se2 solar cells: optimizing the absorber bandgap profile by numerical device simulations, Current Applied Physics, 16 (2016) 1334-1341.

[25] P. Chelvanathan, Y. Yusoff, F. Haque, M. Akhtaruzzaman, M. Alam, Z. Alothman, M. Rashid, K. Sopian, N. Amin, Growth and characterization of RF-sputtered ZnS thin film deposited at various substrate temperatures for photovoltaic application, Applied Surface Science, 334 (2015) 138-144.

[26] W.-H. Ho, C.-H. Hsu, T.-H. Yeh, Y.-H. Chang, S.-Y. Wei, T.-Y. Lin, C.-H. Lai, Room-temperature chemical solution treatment for flexible $\mathrm{ZnS}(\mathrm{O}, \mathrm{OH}) / \mathrm{Cu}(\mathrm{In}, \mathrm{Ga}) \mathrm{Se} 2$ solar cell: improvements in interface properties and metastability, ACS applied materials \& interfaces, 8 (2016) 6709-6717.

[27] B. Abd El Halim, A. Mahfoud, D.M. Elamine, Numerical analysis of potential buffer layer for Cu2ZnSnS4 (CZTS) solar cells, Optik, 204 (2020) 164155.

[28] A. Slonopas, H. Ryan, B. Foley, Z. Sun, K. Sun, T. Globus, P. Norris, Growth mechanisms and their effects on the opto-electrical properties of CdS thin films prepared by chemical bath deposition, Materials Science in Semiconductor Processing, 52 (2016) 24-31.

[29] J. Han, C. Spanheimer, G. Haindl, G. Fu, V. Krishnakumar, J. Schaffner, C. Fan, K. Zhao, A. Klein, W. Jaegermann, Optimized chemical bath deposited CdS layers for the improvement of CdTe solar cells, Solar Energy Materials and Solar Cells, 95 (2011) 816-820.

[30] R. Dharmadasa, B. Lavery, I. Dharmadasa, T. Druffel, Intense pulsed light treatment of cadmium telluride nanoparticle-based thin films, ACS applied materials \& interfaces, 6 (2014) 5034-5040.

[31] W. Cai, L. Feng, Y. Cai, J. Zhang, B. Li, W. Li, L. Wu, Z. Lei, J. Zheng, Produce technology of CdTe thin film modules and design of manufacture line, in: 2006 IEEE 4th World Conference on Photovoltaic Energy Conference, IEEE, 2006, pp. 585-587.

[32] T. Okamoto, Y. Shiina, S. Okamoto, Investigation of Cu-doping effects in CdTe solar cells by junction photoluminescence with various excitation wavelengths, Japanese Journal of Applied Physics, 56 (2017) $08 \mathrm{MC} 02$.

[33] T. Okamoto, R. Hayashi, Y. Ogawa, A. Hosono, M. Doi, Fabrication of polycrystalline CdTe thin-film solar cells using carbon electrodes with carbon nanotubes, Japanese Journal of Applied Physics, 54 (2015) 04DR01.

[34] N.Y. Jamil, M. Ivashchenko, S. Abdulla, A. Muhammed, A. Pogrebnjak, Design and Fabrication Heterojunction Solarcell of Si-CdS-ZnO Thin Film, in: Proceedings of the International Conference Nanomaterials: Applications and Properties, Sumy State University Publishing, 2012, pp. 04NMEEE0904NMEEE09. 
[35] S. Zyoud, A. Zyoud, Effect of Absorber (Acceptor) and Buffer (Donor) Layers Thickness on $\mathrm{Mo} / \mathrm{CdTe} / \mathrm{CdS} / \mathrm{ITO}$ Thin Film Solar Cell Performance: SCAPS-1D Simulation Aspect, International Review on Modelling and Simulations (IREMOS), 14 (2021) 10-17.

[36] N. Naghavi, E. Chassaing, M. Bouttemy, G. Rocha, G. Renou, E. Leite, A. Etcheberry, D. Lincot, Electrodeposition of In2S3 buffer layer for Cu (In, Ga) Se2 solar cells, Energy Procedia, 10 (2011) 155-160. [37] K.B. Adam, H. Miyauchi, Optimization of a Photovoltaic Hybrid Energy Storage System Using Energy Storage Peak Shaving, (2019).

[38] W. Piarah, Z. Djafar, A New Simulation of Photovoltaic and Thermoelectric Generator Hybrid System with a Beam Splitter Cold and Hot Mirror for Low Intensity, International Review of Mechanical Engineering (I. RE. ME), 13 (2019) 559-567.

[39] K. Dib, R. Chenni, A Combined MPPT Algorithm for Photovoltaic Systems Based Arduino Microcontroller, changes, 11 (2018) 12.

[40] M. Burgelman, P. Nollet, S. Degrave, Modelling polycrystalline semiconductor solar cells, Thin solid films, 361 (2000) 527-532.

[41] K. Decock, S. Khelifi, M. Burgelman, Modelling multivalent defects in thin film solar cells, Thin Solid Films, 519 (2011) 7481-7484.

[42] M. Burgelman, J. Verschraegen, S. Degrave, P. Nollet, Modeling thin-film PV devices, Progress in Photovoltaics: Research and Applications, 12 (2004) 143-153.

[43] H. Movla, Optimization of the CIGS based thin film solar cells: Numerical simulation and analysis, Optik, 125 (2014) 67-70.

[44] N. Amin, M. Matin, M. Aliyu, M. Alghoul, M. Karim, K. Sopian, Prospects of back surface field effect in ultra-thin high-efficiency $\mathrm{CdS} / \mathrm{CdTe}$ solar cells from numerical modeling, International journal of photoenergy, 2010 (2010).

[45] N. Amin, A. Yamada, M. Konagai, Effect of ZnTe and CdZnTe Alloys at the Back Contact of 1- $\mu$ m-Thick CdTe Thin Film Solar Cells, Japanese journal of applied physics, 41 (2002) 2834.

[46] T. Aramoto, S. Kumazawa, H. Higuchi, T. Arita, S. Shibutani, T. Nishio, J. Nakajima, M. Tsuji, A. Hanafusa, T. Hibino, 16.0\% efficient thin-film CdS/CdTe solar cells, Japanese Journal of Applied Physics, 36 (1997) 6304.

[47] M. Asaduzzaman, A.N. Bahar, M.M.R. Bhuiyan, Dataset demonstrating the modeling of a high performance $\mathrm{Cu}$ (In, Ga) Se2 absorber based thin film photovoltaic cell, Data in brief, 11 (2017) 296.

[48] M. Asaduzzaman, A.N. Bahar, M.M. Masum, M.M. Hasan, Cadmium free high efficiency Cu2ZnSn (S, Se) 4 solar cell with Zn1- xSnxOy buffer layer, Alexandria engineering journal, 56 (2017) 225-229.

[49] M. Asaduzzaman, M. Hasan, A.N. Bahar, An investigation into the effects of band gap and doping concentration on $\mathrm{Cu}$ (In, Ga) Se 2 solar cell efficiency, SpringerPlus, 5 (2016) 1-8.

[50] M. Asaduzzaman, M. Hosen, M. Ali, A.N. Bahar, Non-toxic buffer layers in flexible Cu (In, Ga) Se2 photovoltaic cell applications with optimized absorber thickness, International Journal of Photoenergy, 2017 (2017).

[51] T. Gessert, P. Sheldon, X. Li, D. Dunlavy, D. Niles, R. Sasala, S. Albright, B. Zadler, Studies of ZnTe back contacts to CdS/CdTe solar cells, in: Conference Record of the Twenty Sixth IEEE Photovoltaic Specialists Conference-1997, IEEE, 1997, pp. 419-422.

[52] S. Hossain, N. Amin, M. Martin, M.M. Aliyu, T. Razykov, K. Sopian, A NUMERICAL STUDY ON THE PROSPECTS OF HIGH EFFICIENCY ULTRA THIN Zn x Cd 1-x S/CdTe Solar Cell, Chalcogenide letters, 8 (2011). [53] Y.-J. Lee, J.L. Gray, Numerical modeling of polycrystalline CdTe and CIS solar cells, in: Conference Record of the Twenty Third IEEE Photovoltaic Specialists Conference-1993 (Cat. No. 93CH3283-9), IEEE, 1993, pp. 586-591.

[54] H. Mahabaduge, W. Rance, J. Burst, M. Reese, D. Meysing, C. Wolden, J. Li, J. Beach, T. Gessert, W. Metzger, High-efficiency, flexible CdTe solar cells on ultra-thin glass substrates, Applied Physics Letters, 106 (2015) 133501. 
[55] A.S. Mirkamali, K.K. Muminov, Simulation of the efficiency of CdS/CdTe tandem multi-junction solar cells, arXiv preprint arXiv:1602.01583, (2016).

[56] R. Kotipalli, O. Poncelet, G. Li, Y. Zeng, L. Francis, B. Vermang, D. Flandre, Addressing the impact of rear surface passivation mechanisms on ultra-thin $\mathrm{Cu}(\mathrm{In}, \mathrm{Ga}) \mathrm{Se} 2$ solar cell performances using SCAPS 1D model, Solar Energy, 157 (2017) 603-613.

[57] N. Limam, A. Belghachi, Analysis of CIGS and CdTe solar cell concentrators, Journal of Ovonic Research Vol, 13 (2017) 129-134.

[58] F.A. Jhuma, M.Z. Shaily, M.J. Rashid, Towards high-efficiency CZTS solar cell through buffer layer optimization, Materials for Renewable and Sustainable Energy, 8 (2019) 1-7.

[59] D. Cozza, C.M. Ruiz, D. Duché, J.J. Simon, L. Escoubas, Modeling the back contact of Cu 2 ZnSnSe 4 solar cells, IEEE Journal of Photovoltaics, 6 (2016) 1292-1297.

[60] D. Avellaneda, M. Nair, P. Nair, Cu2SnS3 and Cu4SnS4 thin films via chemical deposition for photovoltaic application, Journal of the Electrochemical Society, 157 (2010) D346.

[61] M. Minbashi, A. Ghobadi, M. Ehsani, H.R. Dizaji, N. Memarian, Simulation of high efficiency SnS-based solar cells with SCAPS, solar energy, 176 (2018) 520-525.

[62] S.H. Zyoud, A.H. Zyoud, A. Abdelkader, N.M. Ahmed, Numerical Simulation for Optimization of ZnTeBased Thin-Film Heterojunction Solar Cells with Different Metal Chalcogenide Buffer Layers Replacements: SCAPS-1D Simulation Program, (2021).

[63] F. Enam, K. Rahman, M. Kamaruzzaman, K. Sobayel, P. Chelvanathan, B. Bais, M. Akhtaruzzaman, A. Alamoud, N. Amin, Design prospects of cadmium telluride/silicon ( $\mathrm{CdTe} / \mathrm{Si}$ ) tandem solar cells from numerical simulation, Optik, 139 (2017) 397-406.

[64] G. Kartopu, O. Oklobia, D. Turkay, D. Diercks, B. Gorman, V. Barrioz, S. Campbell, J. Major, M. Al Turkestani, S. Yerci, Study of thin film poly-crystalline CdTe solar cells presenting high acceptor concentrations achieved by in-situ arsenic doping, Solar Energy Materials and Solar Cells, 194 (2019) 259267.

[65] T. Ablekim, S.K. Swain, W.-J. Yin, K. Zaunbrecher, J. Burst, T.M. Barnes, D. Kuciauskas, S.-H. Wei, K.G. Lynn, Self-compensation in arsenic doping of CdTe, Scientific reports, 7 (2017) 1-9.

[66] S. Grover, X. Li, W. Zhang, M. Yu, G. Xiong, M. Gloeckler, R. Malik, Characterization of arsenic doped CdTe layers and solar cells, in: 2017 IEEE 44th Photovoltaic Specialist Conference (PVSC), IEEE, 2017, pp. 1193-1195.

[67] A. Kanevce, M.O. Reese, T. Barnes, S. Jensen, W. Metzger, The roles of carrier concentration and interface, bulk, and grain-boundary recombination for $25 \%$ efficient CdTe solar cells, Journal of Applied Physics, 121 (2017) 214506.

[68] C.D. Bailie, M.G. Christoforo, J.P. Mailoa, A.R. Bowring, E.L. Unger, W.H. Nguyen, J. Burschka, N. Pellet, J.Z. Lee, M. Grätzel, Semi-transparent perovskite solar cells for tandems with silicon and CIGS, Energy \& Environmental Science, 8 (2015) 956-963.

[69] K. Wang, O. Gunawan, T. Todorov, B. Shin, S. Chey, N. Bojarczuk, D. Mitzi, S. Guha, Thermally evaporated Cu 2 ZnSnS 4 solar cells, Applied Physics Letters, 97 (2010) 143508.

[70] W. Zhao, W. Zhou, X. Miao, Numerical simulation of CZTS thin film solar cell, in: 2012 7th IEEE International Conference on Nano/Micro Engineered and Molecular Systems (NEMS), IEEE, 2012, pp. 502505.

[71] A. Niemegeers, M. Burgelman, Effects of the Au/CdTe back contact on IV and CV characteristics of $\mathrm{Au} / \mathrm{CdTe} / \mathrm{CdS} / \mathrm{TCO}$ solar cells, Journal of applied Physics, 81 (1997) 2881-2886.

[72] M.M. Islam, S. Ishizuka, A. Yamada, K. Sakurai, S. Niki, T. Sakurai, K. Akimoto, CIGS solar cell with MBEgrown ZnS buffer layer, Solar energy materials and solar cells, 93 (2009) 970-972.

[73] A. Ennaoui, W. Eisele, M. Lux-Steiner, T. Niesen, F. Karg, Highly efficient Cu (Ga, In)(S, Se) 2 thin film solar cells with zinc-compound buffer layers, Thin Solid Films, 431 (2003) 335-339. 
[74] S. Spiering, A. Eicke, D. Hariskos, M. Powalla, N. Naghavi, D. Lincot, Large-area Cd-free CIGS solar modules with In2S3 buffer layer deposited by ALCVD, Thin Solid Films, 451 (2004) 562-566.

[75] G. Kartopu, B. Williams, V. Zardetto, A. Gürlek, A. Clayton, S. Jones, W. Kessels, M. Creatore, S. Irvine, Enhancement of the photocurrent and efficiency of CdTe solar cells suppressing the front contact reflection using a highly-resistive ZnO buffer layer, Solar Energy Materials and Solar Cells, 191 (2019) 7882. 